\title{
Vulnerability of sandy coasts to climate variability
}

\author{
Déborah Idier $^{1, *}$, Bruno Castelle ${ }^{2}$, Marc Poumadère ${ }^{3}$, Yann Balouin ${ }^{1}$, \\ Raquel Bohn Bertoldo ${ }^{3}$, Frédéric Bouchette ${ }^{4}$, Faiza Boulahya ${ }^{1}$, Olivier Brivois ${ }^{1}$, Daniel Calvete ${ }^{5}$, \\ Sylvain Capo ${ }^{2}$, Raphael Certain ${ }^{6}$, Elodie Charles ${ }^{1}$, Eric Chateauminois ${ }^{7}$, Etienne Delvallée ${ }^{1}$, \\ Albert Falqués ${ }^{3}$, Paul Fattal ${ }^{8}$, Manuel Garcin ${ }^{1}$, Roland Garnier ${ }^{9}$, Arnaud Héquette ${ }^{10}$, Philippe Larroudé ${ }^{11}$, \\ Sophie Lecacheux ${ }^{1}$, Gonéri Le Cozannet ${ }^{1}$, Mohamed Maanan ${ }^{8}$, Cyril Mallet $^{1}$, Aurélie Maspataud ${ }^{10}$, \\ Carlos Oliveros ${ }^{1}$, Martin Paillart ${ }^{12}$, Jean-Paul Parisot ${ }^{2}$, Rodrigo Pedreros ${ }^{1}$, Nicolas Robin ${ }^{6}$, Marc Robin ${ }^{8}$, \\ Emmanuel Romieu ${ }^{1}$, Marie-Hélène Ruz ${ }^{10}$, Jérôme Thiébot ${ }^{1}$, Charlotte Vinchon ${ }^{1}$

\footnotetext{
${ }^{1}$ Bureau de Recherches Géologiques et Minières, Direction DRP, 3 avenue C. Guillemin, 45060 Orléans cedex 2, France

${ }^{2}$ Environnements et Paléoenvironnements Océaniques et Continentaux, Université Bordeaux I, avenue des Facultés, 33405 Talence, France

${ }^{3}$ SYMLOG, 262 rue St Jacques, 75005 Paris, France

${ }^{4}$ GEOSCIENCES, CC 60 Université Montpellier 2, 34095 Montpellier cedex 5, France

${ }^{5}$ Universitat Politècnica de Catalunya, C/ Jordi Girona 1-3, Modul B4/B5, despatx 103, 08034 Barcelona, Spain

${ }^{6}$ Centre de Formation et de Recherche sur les Environnements Méditerranéens, UMR5110,

Université de Perpignan Via Domitia, Bat.U, 52 avenue Paul Alduy, 66860 Perpignan cedex 9, France

${ }^{7}$ BRLi, 1105 avenue Pierre Mendès France, BP 4001, 30001 Nîmes cedex, France

${ }^{8}$ Littoral - Environnement - Télédétection - Géomatique, UMR CNRS 6554, Pôle Mer et Littoral, Université de Nantes, BP 8122, 44312 Nantes, France 39005 Santander, Spain

${ }^{10}$ Laboratoire d'Océanologie et de Géosciences, UMR CNRS 8187, Université du Littoral Côte d'Opale, 32 avenue Foch, 62930 Wimereux, France

${ }^{11}$ Laboratoire des Ecoulements Géophysiques et Industriels, BP 53, 38041 Grenoble cedex 9, France

${ }^{12}$ Communauté de Communes de l'île de Noirmoutier, BP 714, rue de la Prée au Duc, 85330 Noirmoutier-en-l'île, France
} \\ ${ }^{9}$ Escuela Técnica Superior de Ingenieros de Caminos de Caminos, Universidad de Cantabria, Avenida de los Castros s/n,
}

\begin{abstract}
The main objective of the VULSACO (VULnerability of SAndy COasts to climate change and anthropic pressure) project was to investigate present day and potential future vulnerability of sandy coasts at the 2030 horizon, i.e. on a time scale related to climate variability. The method, based on a multidisciplinary approach bringing together geologists, geographers, physicists, social psychologists, engineers and stakeholders, was structured around 4 axes: field data analysis; numerical modelling; analysis of governance and stakeholder perceptions; and development of vulnerability indexes. This approach was designed to investigate vulnerability at a local scale and was applied to 4 contrasting beaches located in France: Sète Lido (Mediterranean Sea), Truc Vert and La Tresson beaches (Atlantic Ocean), and Dewulf (English Channel). The results focus on decadal and multi-annual beach trends at the Truc Vert beach site. There is almost no trend in beach volume at Truc Vert beach, although there is a variation in this parameter on a cycle of 2 to $3 \mathrm{yr}$, with variations related to wave energy and probably to indexes of climate variability. Numerical modelling identified the sensitivity of beach responses to changes in wave height and direction, especially in terms of subtidal morphology and the potential development of shoreline instability. Together with the observed offshore wave angle at the Biscay Buoy, these model results suggest that a potential change in wave angle due to climate variability could significantly modify the bars' morphology. The combination of data analysis and numerical modelling contributed to the development of vulnerability indexes designed for sandy coasts, which take into account climate-dependant variables such as waves. This allowed the differentiation of the sites in terms of vulnerability to erosion: Sète Lido and Truc Vert beach were the most and least vulnerable sites, respectively. These indexes help in identifying the dominant components of beach vulnerability, and provide potential for the study of how anthropogenic factors affect vulnerability. The study of stakeholder perceptions and decision-making with regard to climate-related risk also highlighted potential anthropogenic effects on beach vulnerability, and identified possible site-specific outcomes.
\end{abstract}

KEY WORDS: Sandy beach $\cdot$ Modelling $\cdot$ Field data $\cdot$ Stakeholders $\cdot$ Index $\cdot$ Truc Vert $\cdot$ France 


\section{INTRODUCTION}

Forty percent of the world's population lives within $100 \mathrm{~km}$ of the coast, an area that accounts for only about $20 \%$ of global land mass (UNEP/GRID Arenal 2007). These areas are urbanised, with potentially important industrial and economic assets. At the same time, the effect of climate change on coastal areas is an emerging issue. In mainland France, 10\% of the population lives in coastal cities, which cover only $4 \%$ of the territory. Furthermore, in France, $24 \%$ of the coastline is subject to erosion, whereas $44 \%$ is stable and $32 \%$ is accreting (Eurosion 2004). About $35 \%$ of the coast is composed of sand, with half of this sandy coast subject to erosion (Eurosion 2004). Coastal areas are vulnerable to climate change, notably because of rising sea level (Nicholls et al. 2011). As a consequence, adaptive measures are required. Coastal environments are therefore one of the first areas for which general guidelines to estimate the impact and the vulnerability to climate change have been developed (IPCC 2007b). In general terms, vulnerability to climate change can be defined as a function of exposure to climate change, sensitivity of the system, and adaptive capacity (Nicholls et al. 2007) (Fig. 1). It follows from this definition that systems that are highly exposed, sensitive and not able to adapt are the most vulnerable (Allen Consulting 2005). Reducing the vulnerability of coastal areas to climate change therefore requires examination of the exposure of the area of interest to climate change, its sensitivity to the changes and its adaptive capacity. Because the 3 components must be considered in vulnerability analyses, climate adaptation policy requires the estimation of both physical and social vulnerability (Adger et al. 2004). Adaptation options can then be proposed to reduce vulnerability by reducing sensitivity to climate change. Some adaptation measures are already in

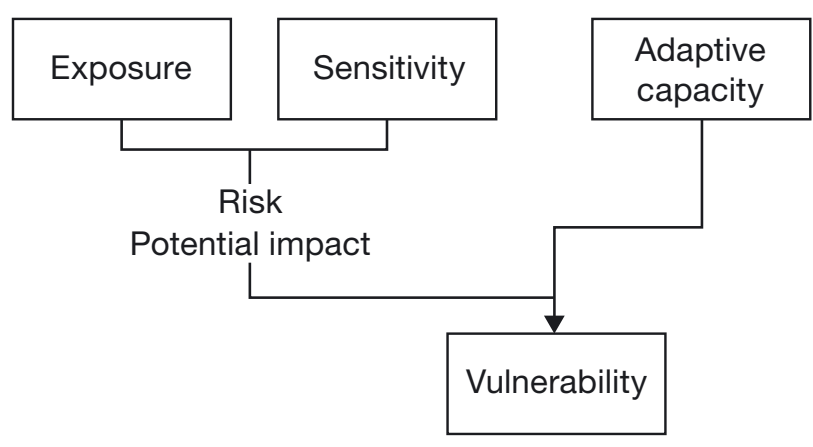

Fig. 1. Vulnerability as a function of exposure, sensitivity and adaptive capacity. Adapted from Nicholls et al. (2007) progress, for instance the restoration of natural lands in the Netherlands (Kabat et al. 2009).

Within this framework, Hall et al. (2006) showed that, based on climate change and socioeconomic scenarios, the risk of coastal flooding is strongly modified by societal vulnerability; 'business as usual' practices in coastal management over the next century would lead to an increase in flood damage. Even if climate change plays a role in this process, the severity of the impact is modulated by both the socioeconomic context and the degree of adaptation to change. Much effort has been made by recent and ongoing projects to improve assessment of the effect of climate change on coastal risks, integrating the socioeconomic component. For instance, the Foresight project (Evans et al. 2004a,b) aimed at analysing the potential future flood risk at the UK-scale over a time frame from 2030 to 2100 . The Response project (McInnes et al. 2006, Vinchon et al. 2009) focussed on regional scales, at different European locations, investigating hazard and risk at the 2100 horizon. The Floodsite project (FLOODsite 2009) analysed both hazards and flood risk mitigation technologies, with a focus on adaptation to climate change, at the scale of estuaries. The ongoing Theseus project (Zanuttigh 2011) investigates the prospects for coastal flood protection in a changing climate. All these projects take into account not only the physical component of the system, but also either socioeconomic projections or potential risk mitigation actions, within a climate change context. Most of them are framed at national or regional scales, and include major coastal cities (Hanson et al. 2011).

This raises scaling issues. While coastal erosion and coastal flooding result directly from local processes (e.g. nearshore waves, surge, tides, decrease of sediment sources, anthropic interruption of longshore sediment transport), these local processes are partly related to ocean-atmosphere dynamics, and thus to the climate, at a basin to global scale. Many interactions and feedbacks between the global and local scale processes are involved, making it difficult to identify relationships between global climate and local phenomena. Thus, downscaling is a challenge in local coastal risk studies, regardless of the selected method (e.g. observations, modelling). There is some evidence of a relationship between the global climate and local hydrodynamic forcing conditions, such as waves (e.g. Woolf et al. 2002, Charles et al. 2012a), mean sea-level (e.g. Woolf et al. 2003, Tsimplis et al. 2005) or storm surges (e.g. Howard et al. 2010). Some studies have investigated possible future hydrodynamic conditions, mainly at the 2100 horizon, fo- 
cussing on waves (e.g. Grabemann \& Weisse 2008, Charles et al. 2012b), sea-level rise (e.g. IPCC 2007a, Slangen et al. 2012) or storm surges (e.g. Woth et al. 2006, Wang et al. 2008, Marcos et al. 2012). In addition to these trends, the high variability of climate cannot be neglected in the study of future hydrodynamic conditions. For instance, Woolf et al. (2003) showed that interannual sea-level variability associated with fluctuations in the North Atlantic Oscillation (NAO) are generally much larger than those associated with secular trends, with inferred multi-decadal fluctuations much larger than the global sea-level rise that occurred in the 20th century and that which is forecasted for the 21st century. Regarding waves, interannual variability has also been found to be much larger than changes associated with the trends on the time scale of decades (Charles et al. 2012a).

In addition to changes in sediment supply, the combination of and interaction between sea-level rise, waves and storm surges should be considered as important factors in coastal evolution (Zhang et al. 2004). For instance, Lozano et al. (2004) showed that the projected 21st century sea-level rise, combined with an increase in storm frequency, would lead to shoreline retreat of 50 to $100 \mathrm{~m}$ on Atlantic sandy coasts. Since $35 \%$ of the French mainland coast is composed of sandy beaches, and coastal areas are intensively used (highly populated, tourist destinations), French coasts are potentially vulnerable in the future. The effects of climate change associated with anthropogenic pressure on French sandy coasts are therefore a matter of concern at different decisionmaking levels (from the European to French local level). This is illustrated by the existence of the ongoing French National Adaptation Plan (PNACC), which aims to plan adaptation actions, prevent inappropriate development and ensure consistency across public policy measures relating to adaptation at a national level, and the Regional Climate, Air and Energy Programmes (SRCAE) for the local level (MEDDE 2011) plan for climate change adaptation (PNACC), put in place for $4 \mathrm{yr}$ starting in 2011. Many programs have also been set up to support research on effects of climate change and coastal vulnerability to climate change and anthropogenic pressures.

Regarding risk management and stakeholders' perceptions of risk, a century is a long time scale, and stakeholders more commonly focus on the decadal scale. On a decadal time scale, the main climate induced effects are related to climate variability rather than climate change Thus, there is a need to investigate the vulnerability of coastal systems to climate variability.
With the aim of addressing the issue of vulnerability of sandy beaches on the time scale of a few decades, the VULSACO (VULnerability of SAndy COasts to climate change and anthropic pressure) project, funded by the French National Research Agency (ANR), started in 2007 and lasted 3.5 yr. One of the underlying aims of this initiative was to bring together scientists working on physical processes, researchers involved in social and human sciences and, if possible, stakeholders, as a first step toward a trans-disciplinary approach towards vulnerability to climate change. The objective of the project was to identify and estimate physical vulnerability indexes for low-lying sandy beaches, as well as to study human perceptions of climate change and their influence on this vulnerability through 2030, especially regarding erosion. The main aim of this paper is to present the general method developed by the VULSACO Project, its application and principal results. First, the method and the 4 study sites are described (Section 2). Then, the application of the method and the main results obtained for one of the 4 sites, i.e. Truc Vert beach, are presented (Section 3). Since the development and application of the vulnerability index is meaningful only for comparing sites, this is discussed in Section 4 for the 4 sites together. Finally, lessons to be learned are identified and conclusions are drawn.

\section{METHODS}

\subsection{General method and sites}

The approach is based on the study of 4 sites that are representative of linear sandy beaches in France (Fig. 2a) and characterised by different hydrodynamic, morphodynamic and socioeconomic environments: Sète Lido (Mediterranean Sea), Truc Vert and La Tresson beaches (Atlantic Ocean), and Dewulf (English Channel). Table 1 summarises the main characteristics of these sites. It should be noted that all these sites except La Tresson are barred beaches, and one underlying research question was how these bars, which protect the beach, might evolve with the climate.

The research program was structured around 4 primary axes (Fig. 2b): (1) data analysis, (2) beach morphodynamic modelling based on a number of different scenarios, (3) governance analysis and (4) development of indexes of vulnerability to erosion.

As shown in what follows, these axes aimed at elucidating the vulnerability of sandy beaches to climate 
a)

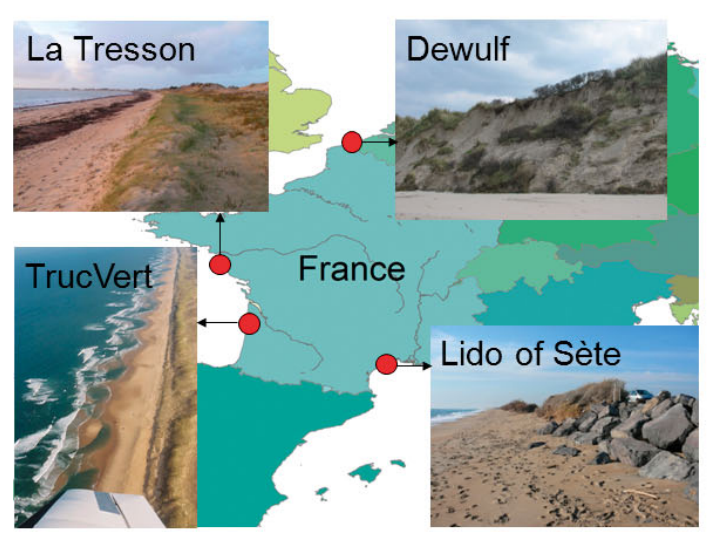

b)
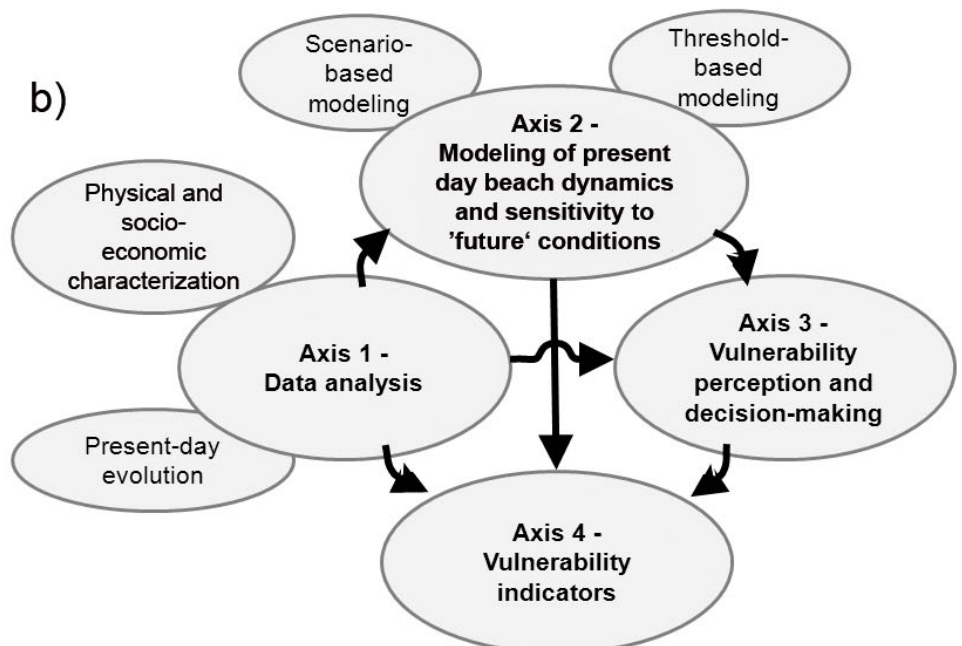

Fig. 2. (a) Study sites in France for the investigation of vulnerability of sandy coasts by the VULSACO (VULnerability of SAndy COast to climate change and anthropic pressure) project. (b) Structure of the research programme

Table 1. Vulnerability of sandy coasts to climate change: main characteristics of study sites in France

\begin{tabular}{|c|c|c|c|c|c|c|c|c|}
\hline $\begin{array}{l}\text { Site } \\
\text { number }\end{array}$ & $\begin{array}{c}\text { Site } \\
\text { name }\end{array}$ & Region & Coast & $\begin{array}{c}\text { Wave exposure } \\
\text { (annual averaged } \\
\text { significant wave } \\
\text { height }\left[H_{\mathrm{s}}\right] \text { ) }\end{array}$ & $\begin{array}{l}\text { Tidal range } \\
\text { (mean spring } \\
\text { tide) }\end{array}$ & $\begin{array}{l}\text { Sediment } \\
\text { stock }\end{array}$ & Urbanization & References \\
\hline 1 & Sète Lido & $\begin{array}{l}\text { Languedoc- } \\
\text { Roussillon }\end{array}$ & $\begin{array}{c}\text { Mediterranean } \\
\text { Sea }\end{array}$ & $\begin{array}{l}\text { Low } \\
(0.8 \mathrm{~m})\end{array}$ & $\begin{array}{c}\text { Low } \\
(<0.4 \mathrm{~m})\end{array}$ & Low & High & $\begin{array}{l}\text { Certain \& Barusseau } \\
(2005)\end{array}$ \\
\hline 2 & Truc Vert & Aquitaine & $\begin{array}{c}\text { Atlantic } \\
\text { Ocean }\end{array}$ & $\begin{array}{l}\text { High } \\
\text { (1.6 m) }\end{array}$ & $\begin{array}{c}\text { Medium } \\
(3.8 \mathrm{~m})\end{array}$ & High & Low & $\begin{array}{l}\text { Castelle et al. (2007), } \\
\text { Sénéchal et al. (2009), } \\
\text { Almar et al. (2010) }\end{array}$ \\
\hline 3 & La Tresson & $\begin{array}{l}\text { Pays-de- } \\
\text { Loire }\end{array}$ & $\begin{array}{l}\text { Atlantic } \\
\text { Ocean }\end{array}$ & $\begin{array}{l}\text { Moderate } \\
\quad(1 \mathrm{~m})\end{array}$ & $\begin{array}{l}\text { Medium } \\
(4.7 \mathrm{~m})\end{array}$ & Medium & Medium & Fattal et al. $(2010)^{a}$ \\
\hline 4 & Dewulf & $\begin{array}{l}\text { Nord Pas de } \\
\text { Calais }\end{array}$ & $\begin{array}{l}\text { English } \\
\text { Channel }\end{array}$ & $\begin{array}{l}\text { High } \\
(1.5 \mathrm{~m})\end{array}$ & $\begin{array}{l}\text { High } \\
(5.45 \mathrm{~m})\end{array}$ & High & Medium & $\begin{array}{l}\text { Maspataud et al. (2009), } \\
\text { Ruz et al. (2009) }\end{array}$ \\
\hline
\end{tabular}

variability (mainly Axes 1 and 2) and how vulnerability is affected by human actions (mainly Axes 3 and 4).

There are logical links and interactions between these axes. In particular, the data analysis (Axis 1) provides information necessary for all the other axes, whereas modelling (Axis 2) contributes to the analysis of governance and development of the vulnerability indexes (Axes 3 and 4). Drawing on reviews of trends and variability of contemporary and future sea-level rise (e.g. Meyssignac \& Cazenave 2012a, Slangen et al. 2012), including at the regional scale in the Bay of Biscay and in the Mediterranean Sea (Marcos \& Tsimplis 2008, Chust et al. 2011, Wöppelmann \& Marcos 2012), we hypothesised that sealevel rise can be considered negligible in the next
20 yr with respect to the erosive processes considered in this study. As we focussed on a time scale of $20 \mathrm{yr}$, sea-level rise was not considered explicitly in this study.

\subsection{Data analysis}

Axis 1 (Fig. 2b) analysed data for each site in terms of: (1) the local effect of climate change, (2) physical, environmental and socioeconomic characteristics of the site, and (3) beach trends. These preliminary investigations provided the basic elements required to analyse beach dynamics (topo-bathymetric evolution, hydrodynamic forcing conditions) at the decadal scale, as well as on short time scales (i.e. a few days). 
This analysis aimed to detect potential relations between beach dynamics and climate variability. In the present project, Axis 1 provided the data required for Axes 2, 3 and 4, i.e. input data for modelling (Axis 2), information about the site for presentation to stakeholders (Axis 3), and knowledge and data for setting up and computing indexes (Axis 4).

\subsection{Modelling}

Axis 2 (modelling) was directly based on the data analysis axis (Fig. 2b). Field measurements as well as knowledge of the hydrodynamic climate (waves, tides, storm surges) were required to set up and validate the model. Modelling was used to study the behaviour of each system in the present-day climate and to estimate its sensitivity to climate variability at the 2030 horizon. Over this time period, several time scales are involved. One is more related to the scale of events such as storms or quiet weather periods (i.e. a few days). The second time scale is more related to annual or multiannual beach behaviour. The VULSACO project addressed both these 2 scales.

First, the models were set up and validated using field data (wave, current and topo-bathymetric data). For the next stage, 2 main strategies were adopted. Strategy 1 (climate-based analysis): This consisted of setting up models of real cases, defining the present day climate scenario and a climate variability-based scenario, running models for these scenarios, computing model output indicators, and finally comparing results among models and among scenarios. Within this climate-based approach, in order to synthesise possible combinations of factors controlling the beach response, a limited number of scenarios were designed. A scenario is characterised by a set of idealised beach morphology and offshore water level and wave characteristics. The scenario construction is described in detail in its application to the Truc Vert site in Section 3.3.1. The models were then run for each scenario and the results analysed using a tool built to derive indicators from the model hydrodynamics and morphology outputs.

Strategy 2 (threshold-based analysis): This consisting of setting up models of idealised cases, proceeding to a sensitivity study of selected parameters, and finally identifying the parameter thresholds leading to a change in the system behaviour. Within this threshold-based approach, the models were used to investigate the sensitivity of beaches to a limited number of offshore input parameters. This allowed thresholds effects to be identified, i.e. when a slight change in offshore hydrodynamics conditions leads to important change in beach dynamics, as, for instance, the complete disappearance of sub-tidal bars.

Both modelling strategies provided inputs for presentations of sites to stakeholders (Axis 3), and contributed to a better knowledge of beach behaviour to support the development of indexes (Axis 4).

In the application of both strategies, taking account of the complexity of beach systems, and especially the interactions between shoreline evolution and bar dynamics (Thornton et al. 2007), we chose to use nearshore morphodynamic models, rather than models based on semiempirical approaches to estimate longshore sediment flux (e.g. Allard et al. 2008) and shoreline evolution on time scales of decades (e.g. Genesis software; Hanson \& Kraus 1989). While such semiempirical models assume a time-invariant beach profile, nearshore morphodynamic models can simulate beach evolution on time scales from days to months with fair accuracy. However, the degree of accuracy can vary significantly depending on (1) the field site (e.g. nearshore morphology, sediment size); (2) the dominant sediment transport (longshore versus cross-shore); (3) the modal wave conditions (high energy versus low energy) and (4) which model one uses. Thus, to better assess the validity of model predictions, 3 to 6 models were applied at each study site from among: TELEMAC (Larroudé, 2008), MORPHODYN (Castelle et al. 2010), MARSOUIN (Bruneau et al. 2007), 1d-morfo (Falqués \& Calvete 2005), Morfo60 (Calvete et al. 2005), Morfo55 (Garnier et al. 2008), Mike 21 (from DHI, www.dhisoftware.com/Products/ CoastAndSea/MIKE21.aspx), X-beach (Roelvink et al. 2009). As an example, Table 2 summarises the main characteristics of the models applied to the Truc Vert site. At the beginning of the VULSACO project (2007), these models were chosen because they were either state-of-the-art research models (e.g. nearshore morphodynamic model Morfo55; Garnier et al. 2008), or widely used engineering tools (e.g. TELEMAC; Hervouet \& Bates 2000).

\subsection{Governance analysis}

Axis 3 (Fig. 2b) aims to characterise the governance through analysis of stakeholders' perception of risk, as well as of their potential adaptation options in the face of damaging events (e.g. storm induced flooding leading to destruction of buildings or roads). The method applied to study governance in response to climate change was as follows : (1) identification of stakeholders; (2) telephone interviews of stakehold- 
Table 2. Synthesis of the morphodynamic models used on Truc Vert beach. Modelling approaches used were: C = climatebased; $\mathrm{T}=$ threshold-based (see text for further explanation)

\begin{tabular}{|c|c|c|c|c|c|}
\hline Model & Morphological output & Event scale & $\begin{array}{c}\text { Annual to } \\
\text { decadal scale }\end{array}$ & $\begin{array}{l}\text { Modelling } \\
\text { approach }\end{array}$ & Reference \\
\hline \multirow[t]{2}{*}{ TELEMAC } & Bathymetry evolution & $x$ & & $\mathrm{C}$ & Larroudé (2008) \\
\hline & Sediment mobility & $x$ & $x$ & $\mathrm{C}$ & \\
\hline MORPHODYN & Bathymetry evolution & $x$ & & $\mathrm{C}$ & Castelle et al. (2010) \\
\hline MARSOUIN & Bathymetry evolution & $x$ & & $\mathrm{C}$ & Bruneau et al. (2007) \\
\hline 1d-morfo & $\begin{array}{c}\text { Shoreline evolution, } \\
\text { using time-variant } \\
\text { equilibrium beach profile }\end{array}$ & $x$ & $x$ & $\mathrm{~T}$ & Falqués \& Calvete (2005) \\
\hline Morfo60 & Bathymetry evolution & $x$ & & $\mathrm{C}, \mathrm{T}$ & Calvete et al. (2005) \\
\hline Morfo55 & Bathymetry evolution & $x$ & & $\mathrm{~T}$ & Garnier et al. (2008) \\
\hline
\end{tabular}

ers; (3) distribution of questionnaires to stakeholders; and (4) 2030 decision-making simulation, with stakeholders playing their current roles. For these simulations, fictive but plausible 2030 scenarios of storm events were designed based on modelling results. To help stakeholders participate in the role play, fictive journal articles were written describing the storm and its impacts.

\subsection{Vulnerability indexes}

Coastal management often requires the use of vulnerability indexes to help the decision-making process. In the present study, the construction of such indexes (Axis 4, Fig. 2b) drew on existing knowledge of vulnerability indexes, and also on the identification of key parameters based on the results of data analysis, modelling and the governance study. This axis aimed at summarizing beach vulnerability to erosion in terms of index values. To achieve this objective, based on the review of existing vulnerability indexes, 4 indexes were selected and applied to the 4 sites to estimate their vulnerability at event (Zhang et al. 2001, Sallenger 2000) and decadal (Coelho et al. 2006, Gornitz 1990, Gornitz et al. 1994) time scales. This was complemented by an analysis of the limits of each of these indexes. The model results (especially those obtained with the models Morfo55, Morphodyn, Marsouin and 1d-morfo related to the sensitivity to wave direction; Table 2), and field knowledge were used to support the development of new sandy beach indexes of vulnerability to climate change that takes account of human actions and decisions.

\section{TRUC VERT SITE RESULTS}

This section presents the results obtained for Axes 1 (data analysis), 2 (modelling) and 3 (governance) at the Truc Vert site.

\subsection{Site description}

Truc Vert beach, SW France, is located on the sandy spit of Lege Cap Ferret (Fig. 3) which formed 2000 yr ago (Tastet \& Nigel 1998) under the influence of a southerly longshore drift, which progressively shifted the opening of the Eyre River southward. The Cap Ferret spit has migrated about $10 \mathrm{~km}$ southwards within $2000 \mathrm{yr}$, and is still active under the influence of waves and tidal currents of the Arcachon

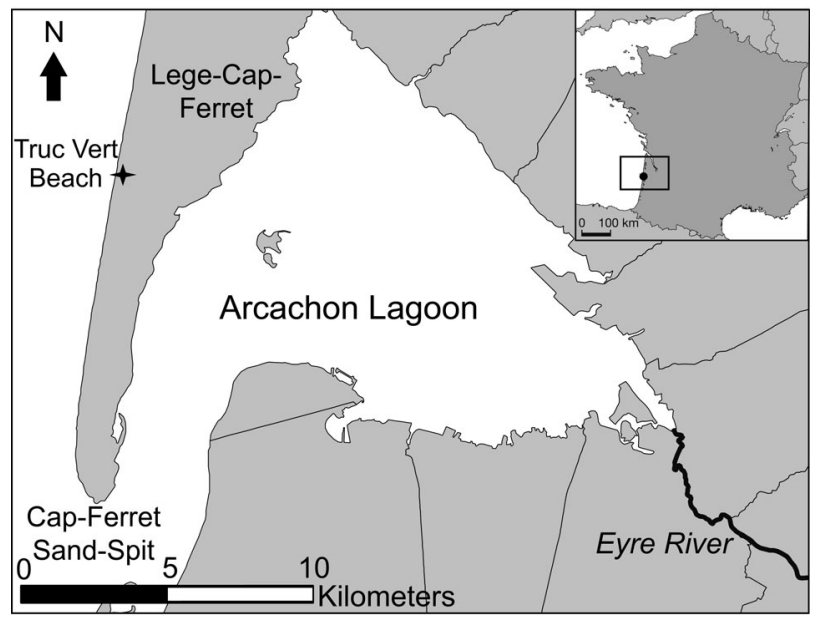

Fig. 3. Location of Truc Vert beach 
Basin inlet. At the north end of the spit (i.e. Truc Vert beach), the coast is not affected by the tide-induced currents at the inlet, and the estimated longshore drift is about $700000 \mathrm{~m}^{3} \mathrm{yr}^{-1}$ (Michel \& Howa 1994).

Truc Vert beach is a non-engineered high-energy open beach, almost north-south oriented, bordered by high aeolian foredunes. The tide is semi-diurnal with an annual mean spring tide range of $3.7 \mathrm{~m}$. Wave climate is characterised by an annual mean significant wave height $\left(H_{\mathrm{s}}\right)$ and period of $1.4 \mathrm{~m}$ and 6.5 s, respectively (Butel et al. 2002). Higher waves occur in autumn and winter, with typical offshore severe storm waves with $H_{\mathrm{s}} \approx 10 \mathrm{~m}$. The sediment consists primarily of medium-grained quartz sand with a median diameter of about $0.35 \mathrm{~mm}$. Truc Vert Beach is intermediate double-barred with the inner bar and outer bar generally exhibiting bar and rip morphology and crescentic patterns, respectively (Castelle et al. 2007).

The Truc Vert site is mainly an environmental asset (beach, dune, forest). However, the Cap Ferret sand spit is integrated in the economy of the Arcachon Basin, which is highly urbanised, and possesses tourism and shellfish-farming assets. The Cap Ferret headland is also urbanised, with a high proportion of secondary residences (>31\%). Inland from the dune system of the Truc Vert beach, LègeCape-Ferret city is characterised by 'green' tourism development. There is no coastal defence at LègeCap-Ferret city.

The whole coastal zone is subject to a range of environmental protection regulations: Natural Zone of Interest for Ecology, Flora and Fauna (a national French inventory program aiming at collecting exhaustive and up-to-date information on the natural environment, whether land- or water-based, and whose interest lies either in the balance or richness of the ecosystem, or in the presence of rare or endangered plant or animal species), Natura 2000 (a Europe-wide network of sites tasked with the preservation of natural heritage), Birds Directive (Directive 2009/147/EC of the European Parliament and of the Council of 30 November 2009 on the conservation of wild birds; (this is the codified version of Directive 79/409/EEC as amended). For instance, Natura 2000 works to reduce aeolian dune erosion by restoring the degraded parts of the coastal dune. It is also involved in public access to the beach. The Truc Vert forest is a National Forest, and as such is maintained by the National Forest Office (ONF). A plan for the prevention of coastal erosion and flooding risk is in place along the entire coast of the Gironde department, including the Truc Vert site area.

\subsection{Data analysis: beach dynamics and temporal variability}

First, we investigated the temporal evolution of the coastline, from 1966 to 2009. Measures of shoreline evolution were made through photointerpretation of orthophotos (with a spatial resolution better than or equal to $0.5 \mathrm{~m}$ ) or Differential Global Positioning System (DGPS) surveys. The shoreline was considered as the boundary between beach and dune, which is characterised by morphological indicators (for example the base of the dune cliff, vegetation, foredune, etc., depending on the circumstances). The analysis (Fig. 4) showed a general tendency of moderate marine erosion $(\sim 1 \mathrm{~m}$ $\mathrm{yr}^{-1}$ ), with alternating periods of erosion equilibrium and accretion. Some ongoing soft human intervention (e.g. restoring dune vegetation to reduce aerial sand transport) has taken place over the last $50 \mathrm{yr}$, probably influencing the shoreline evolution in a positive way. At the end of the 19th century, a

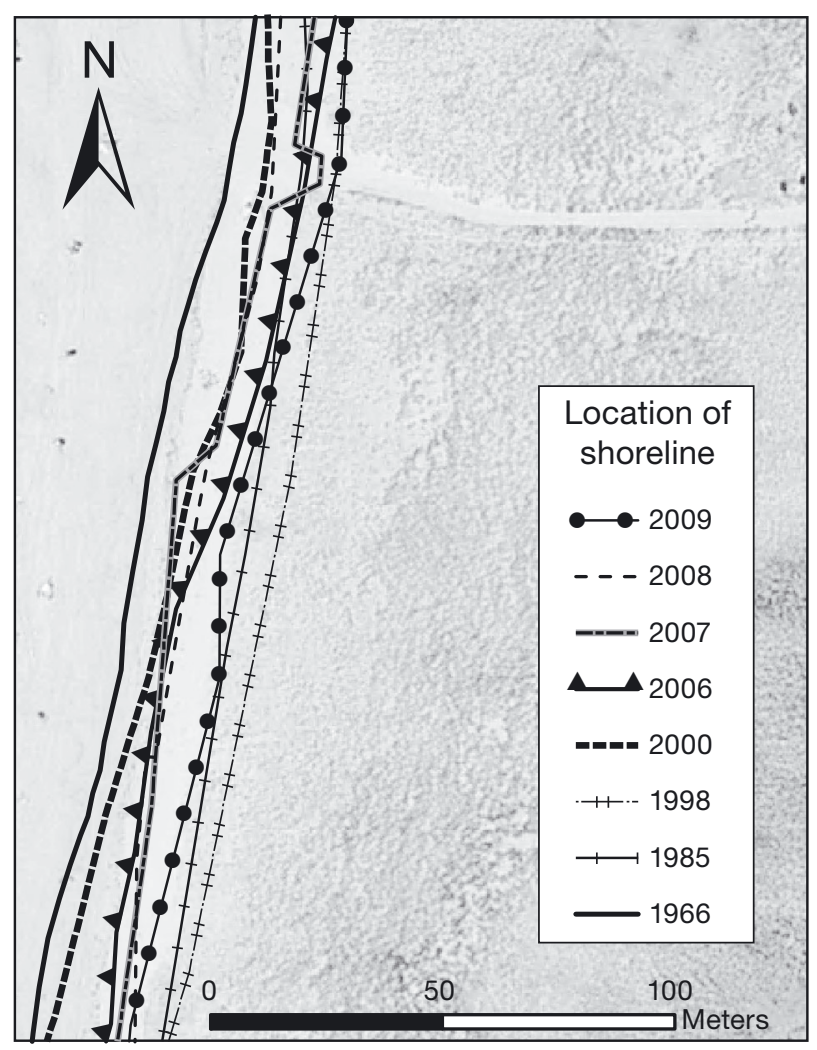

Fig. 4. Shoreline position from 1966 to 2009 at Truc Vert beach. The shoreline shown is the high water mark, i.e. the boundary between dune and beach. Background imageprojection system: RGF 93 / Lambert 93; Copyright: Orthophoto 2009 IGN (GIP ATGeRI); dataset: BRGM Aquitaine Coast Observatory ( $40 \mathrm{~cm}$ resolution) 
forest of maritime pine was planted just inland of the Aquitaine coastal dune system to reduce its mobility. In Fig. 4, the maximal range between coastline positions is about $30 \mathrm{~m}$, corresponding to an erosion between the first survey (1966) and the one carried out in 1998.

In order to investigate the temporal variability of the beach and how it could be linked to climate variability, we analysed a 14-yr topographic dataset, and compared it to wave data. The data used was from regular topographic surveys that have been carried out at Truc Vert beach by the EPOC laboratory (EPOC: Environnements et Paléoenvironnements Océaniques et Continentaux) at the University of Bordeaux 1 since 1997 (Sénéchal et al. 2009). Surveys are carried out monthly at spring low tides from the dune foot to the low-tide waterline, resulting in beach profile data with an average cross-shore length of about $400 \mathrm{~m}$, using a theodolite from 1997 to 2003 and a kinematic GPS since 2003. Additional surveys were carried out for specific purposes (e.g. during intensive field research). A number of gaps exist in the dataset, due mostly to technical problems and faulty data acquisition. Wave data over the 1997-2012 period were obtained from the NWW3 model (Tolman 1991) at the nearest grid point. Wave energy at the beach was estimated through the wave induced energy flux $F_{\text {, }}$ computed using the formula of Larson et al. (2000), such that $F=\rho T_{\mathrm{p}} g H_{\mathrm{s}}^{2} / 32 \pi$ where $T_{\mathrm{p}}$ is the wave peak period, $\rho$ is the sediment mass density and $g$ is gravitational acceleration. Here, we discuss the temporal evolution of volume of the intertidal and upper part of the beach, i.e. between the lowest tide level and dune foot. This volume is computed every month. Results show that beach volume is seasonally modulated as a result of higher wave energy in winter than in summer (Parisot et al. 2010). The time series of the beach volume and $F$ show a marked negative correlation (Fig. 5). Fig. 5 also suggests a modulation of beach volume on longer timescales (2 to $4 \mathrm{yr}$ ). As fluctuations in the North Atlantic Oscillation (NAO) occur at similar timescales and as NAO has been found to impact the wave climate in Bay of Biscay (e.g. Le Cozannet et al. 2011, Charles et al. 2012a), the long-term variations in beach volume are presumably related to this global climate index.

Similar observations were made by Ranasinghe et al. (2004), who related beach rotation to the El Niño Southern Oscillation (ENSO) index in Australia. This evidence of a relation between beach volume and wave energy fluctuation is also consistent with other studies showing correlations between beach dynamics and the NAO index on the Baltic Sea coast (Poland; Rozynski 2010) and in West Wales (UK; Thomas et al. 2010, 2012). However the period of our dataset is not long enough to rigorously test the hypothesis of correlation between beach volume and NAO at the Truc Vert beach. There is a need for more in-depth analysis to identify such a correlation.

To summarise the results of the analysis, there is almost no trend in beach volume at Truc Vert beach, although there is a variation in this parameter on a cycle of 2 to $3 \mathrm{yr}$, with variations related to wave energy and probably to indexes of climate variability (such as the NAO index). This null trend observed on this period is consistent with the shoreline evolution based on photo-interpretations and GPS surveys done between 1998 and 2006: from 1998 to 2000 a shoreline advance is observed, followed by a retreat between 2000 and 2006. This illustrates the temporal oscillation of shoreline. a

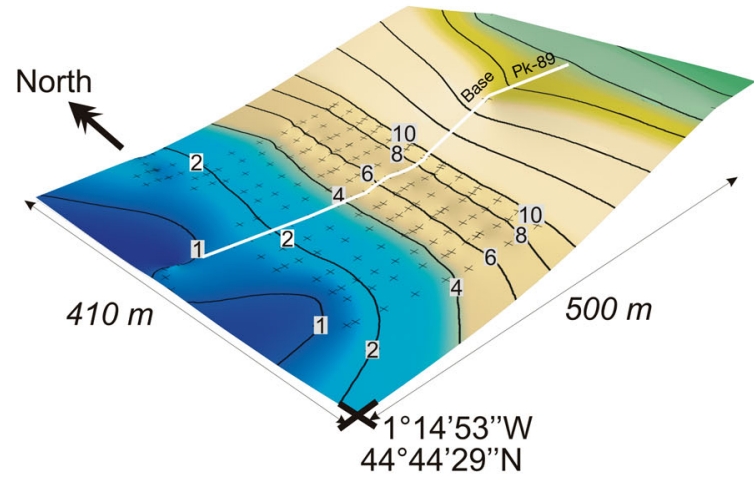

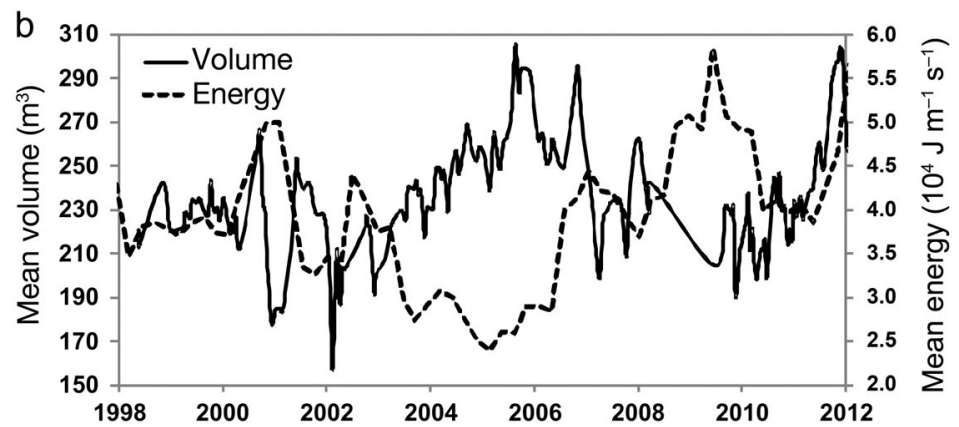

Fig. 5. (a) Topo-bathymetry of Truc Vert beach with superimposed reference cross-shore profile. (b) Time series of the beach sand volume (along the main profile) and wave energy flux. Adapted from Parisot et al. (2010) 


\subsection{Morphodynamic modelling}

\subsubsection{Short-term / climate-based modelling}

Model set-up and limits. For Truc Vert beach, the nonlinear morphodynamic models TELEMAC (Larroudé 2008), MORPHODYN (Castelle et al. 2010) and MARSOUIN (Bruneau et al. 2007) were used to simulate beach evolution on time scales of days to weeks. These 3 models couple a spectral wave model, a depth-averaged flow model, a sediment transport model, and the bed level continuity equation to compute bed level changes. They are based on different parameterisations and numerical schemes, yet they all contain the essential physics to address 3D beach morphodynamics. In particular, starting from an alongshore-uniform beach (typical of post-storm conditions) these models are able to reproduce and unravel the underlying physics of the formation of 3D surf zone patterns such as bar and rip morphologies and crescentic plan shapes (e.g. Castelle \& Ruessink 2011). This corresponds to the so-called down-state sequence following the morphological framework of Wright \& Short (1984), which has been extensively observed along intermediate beaches. A serious limitation of these 3 models, and all the other morphodynamic models developed worldwide, is that they fail to reproduce up-state sequences, that is, the reshaping of 3D surfzone sandbar patterns into alongshore-uniform bars during storm events. Accordingly, these models cannot be used to address beach morphodynamics on long time scales (e.g. from 2010 to 2030), i.e. during periods long enough to include storm waves. Thus, within the present study, the scenario-based sensitivity analysis focussed only on cases corresponding to down-state sequence.

Prior to the morphodynamic simulations, the hydrodynamics module (waves and wave-driven currents) of the 3 models was validated with the ECORS'08 (international field experiment on the sandy Truc Vert beach hydrodynamics and morphodynamics) field data (Almar et al. 2010) on a 4-d period (Fig. 6a). This period was chosen because of the availably of topo-bathymetric and hydrodynamic data for a same period (Fig. 6). Simulations were in fair agreement with measurements (Fig. 6c,d), justifying the use of these models to undertake further morphodynamic simulations.

Scenario construction. Bearing in mind the limitations described above, the models were used to simulate multi-variable scenarios, and thus to investigate the sensitivity of beach systems to climate variability. First, we describe the scenarios for Truc
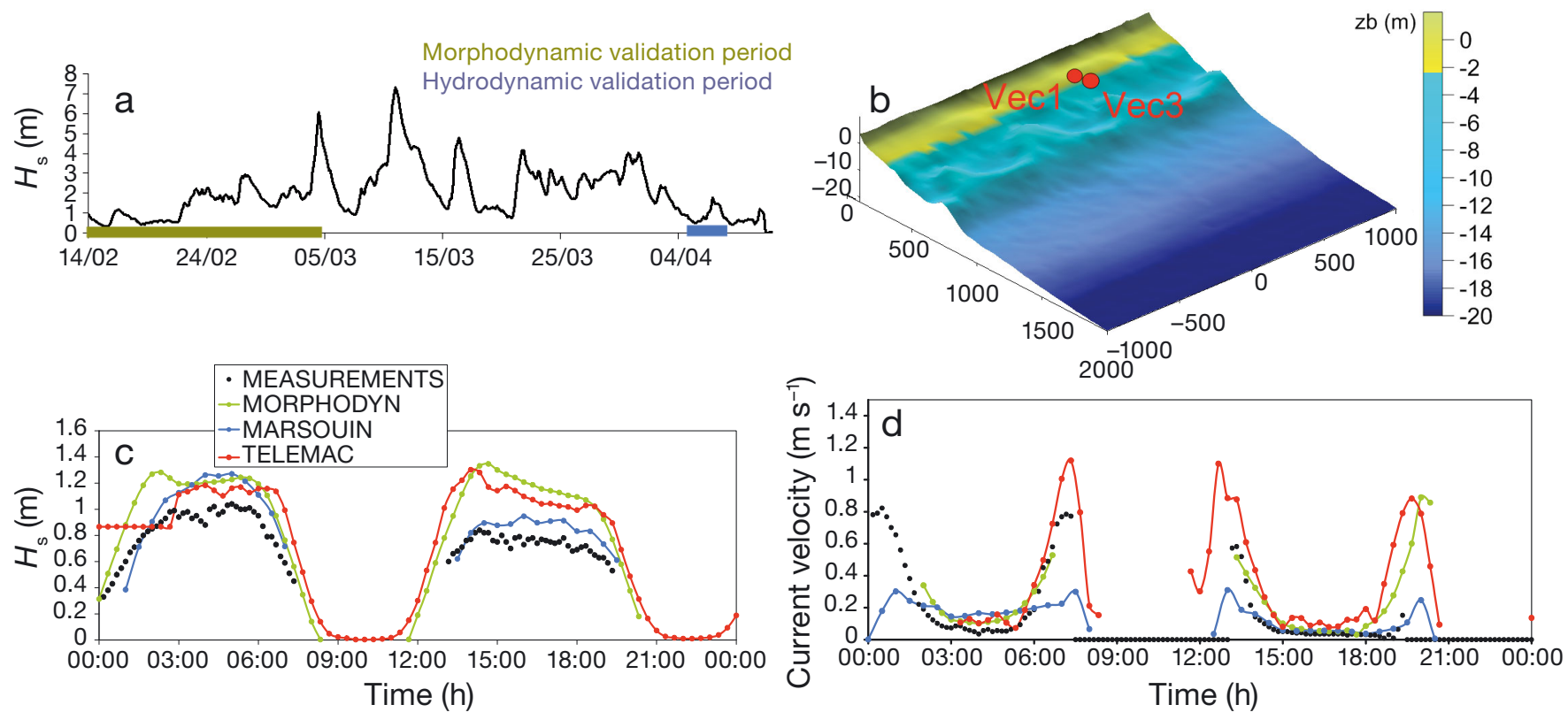

Fig. 6. (a) Significant wave height $\left(H_{\mathrm{s}}\right)$ at the Truc Vert beach measured offshore in $20 \mathrm{~m}$ water depth during the ECORS'08 experiment (Sénéchal et al. 2011). Coloured bars show the periods chosen for the hydrodynamic (blue) and morphodynamic (green) validation of the models. Dates are dd/mm in 2008. (b) Bathymetry (zb is the sea-bed level relative to the IGN69 frame) and location of the current meters Vec1 and Vec3. (c) Measurements of $H_{\mathrm{s}}$ and (d) current velocity made at the Vec1 sensor position on 7 April 2008 and comparison with values obtained in simulations using the MARSOUIN, TELEMAC and MORPHODYN models (see Table 2) 

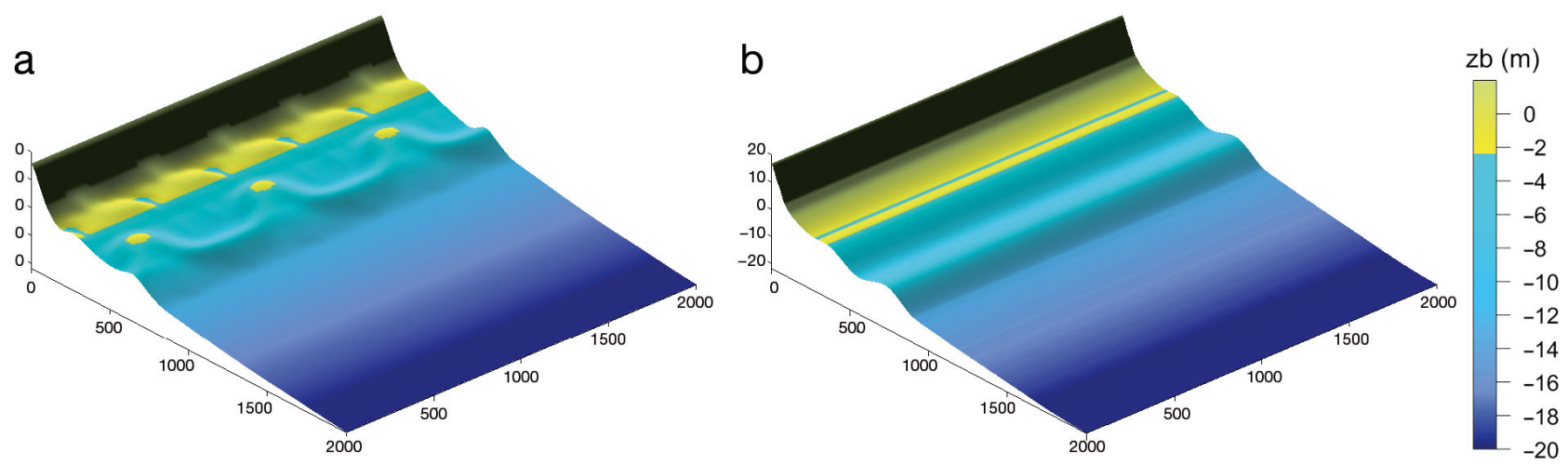

Fig. 7. Idealised bathymetries used in the sensitivity study: (a) quiet weather; (b) stormy conditions. zb is the seabed level relative to the vertical reference IGN69 (lowest astronomical tide at $-2.28 \mathrm{~m}$ )

Vert beach that were co-designed by modellers and field investigators. The objective of creating these scenarios was to provide initial configurations (bathymetry and hydrodynamic boundary conditions) of the models in order to determine the extent to which climate variability can modify the morphological behaviour of the beach.

Initial configurations (also called present-day scenarios) were based on in situ measurements (mainly: bathymetry, waves, and water level), model outputs (wave characteristics propagated to the coast) and empirical observations. The initial bathymetry is crucial to the subsequent evolution of a beach (Calvete et al. 2007). Thus, 2 types of morphologies were used, one representative of an extended period of beach recovery $(3 \mathrm{D}$ bathymetry), and the other of stormy conditions (alongshore-uniform bathymetry). Fig. 7 shows the 2 corresponding bathymetries.

A wave classification algorithm $(\mathrm{Bu}-$ tel et al. 2002, Le Cozannet et al. 2011) was used to synthesise the wave time series with a limited number of wave classes $\left(4\right.$, defined by $H_{\mathrm{s}}$ peak period $\left[T_{\mathrm{p}}\right]$ and peak direction $\left.\left[D_{\mathrm{p}}\right]\right)$, representative of present-day conditions. The last parameter prescribed in the scenario was the water level. In the present-day scenarios, 3 water level configurations were considered, based on the mean spring tide and 3 storm surge conditions $(0,50$ and $100 \%$ of the maximal storm surge observed to date).

For the variability scenarios at the 2030 horizon, we assumed that the beach profile keeps an equilibrium shape that translates upward and landward as sea-level rises. Thus, sea-level rise is not explicitly taken into account. Scenarios of variability of future wave conditions were based on Charles et al. (2012a) who investigated the present-day wave climate on the Aquitanian coast through numerical modelling over a long period (1958 to 2001). Accordingly, a range of future variations of up to $\pm 10 \%$ wave height and $\pm 10^{\circ}$ wave direction were considered (Fig. 8). For storm surges, we assumed an increase in the maximum storm surge of $+20 \%$. These water level variations were selected in order to produce significant changes in the beach response, assuming that such variations could occur. Overall,
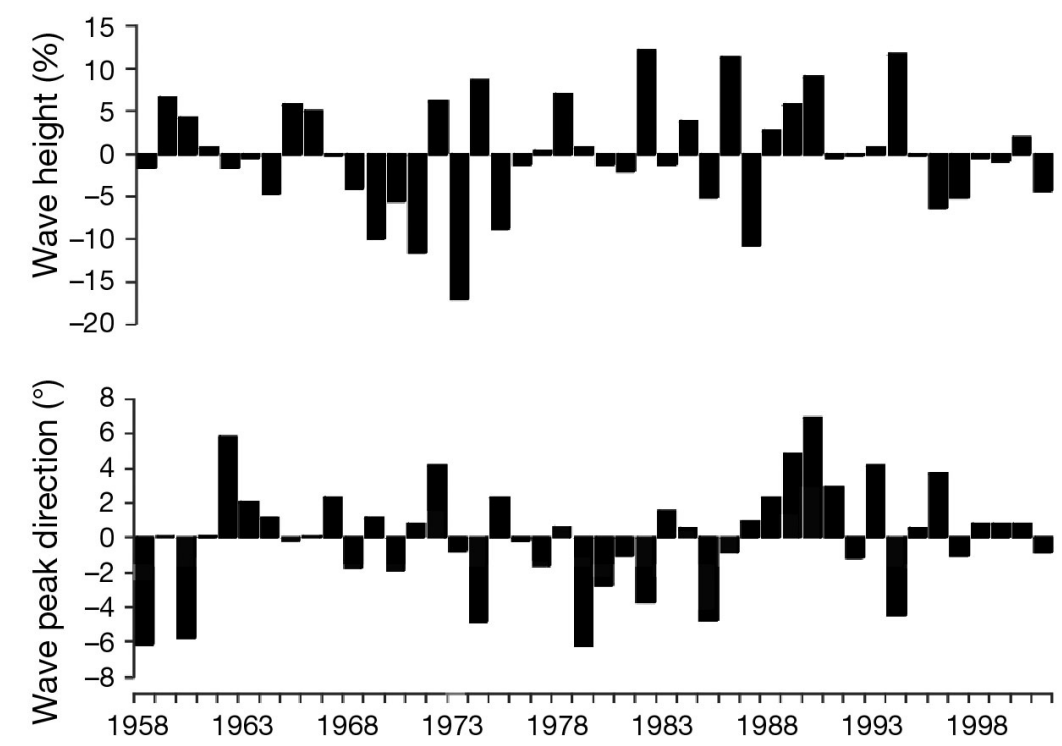

Fig. 8. Time series of (a) relative wave height and (b) wave direction at the Biscay Buoy $\left(45^{\circ} \mathrm{N}, 5^{\circ} \mathrm{W}\right)$ from 1958 to 2001 . The relative annual significant wave height is the yearly averaged significant wave height divided by the annual significant wave height averaged over the entire period. The relative annual wave peak direction is the yearly averaged peak direction minus the annual wave peak direction averaged over the entire period. Data from Charles et al. (2012a) 
260 scenarios were generated, run and analysed for Truc Vert beach.

Scenario simulation. Idier et al. (2011a) performed a first analysis of the model results obtained for all the down-state transition scenarios, and especially for the alongshore-uniform bathymetry scenarios. These computations give some first indications, which need to be confirmed, of the potential influence of wave climate variability. Indeed, 2 of the 3 models show that the magnitude of the seabed evolution at Truc Vert beach is mainly sensitive to changes in the wave class and the $\pm 10^{\circ}$ wave direction, rather than the water level (tide and storm surges) or the $\pm 10 \%$ wave height variation within each class. This implies that Truc Vert beach morphodynamics could be modified as a result of a change in the frequency of occurrence of wave classes or a change in mean wave incidence. Based on these first results, we used the threshold-based modelling approach to investigate the influence of wave characteristics on the beach system.

\subsubsection{Short-term / threshold-based modelling}

As it was identified as a critical parameter, the impact of wave incidence was studied in more depth through a linear stability analysis (Brivois et al. 2012) and a nonlinear stability analysis (Thiébot et al.
2012). Brivois et al. (2012) investigated the morphological behaviour of the double bar system of Truc Vert beach. Using a limited number of combinations of representative bathymetries, wave classes and water levels, the morphodynamic response of the system was analysed, focussing on the geometrical characteristics of 3D patterns generated with the model. The shapes and the wavelengths of the instabilities predicted by the model compare well with field observations, suggesting that the main processes responsible for 3D pattern formation were properly taken into account in the model. Based on this conclusion, Thiébot et al. (2012) used the nonlinear morphodynamic morfo55 model to investigate the sensitivity of a double bar beach, like the Truc Vert site, to wave incidence. This model was based on the same physical processes as the one used by Brivois et al. (2012), who showed that wave incidence is crucial to the morphodynamics of such a system. Four types of morphodynamic response, essentially controlled by wave incidence, were identified (Fig. 9). These morphologies are similar to those typically observed along barred beaches (e.g. van Enckevort et al. 2004). Together with the observed offshore wave angle variability at the Biscay buoy, these results suggest that a potential change in wave angle due to climate variability could significantly modify the frequency of occurrence of those 4 morphologies.
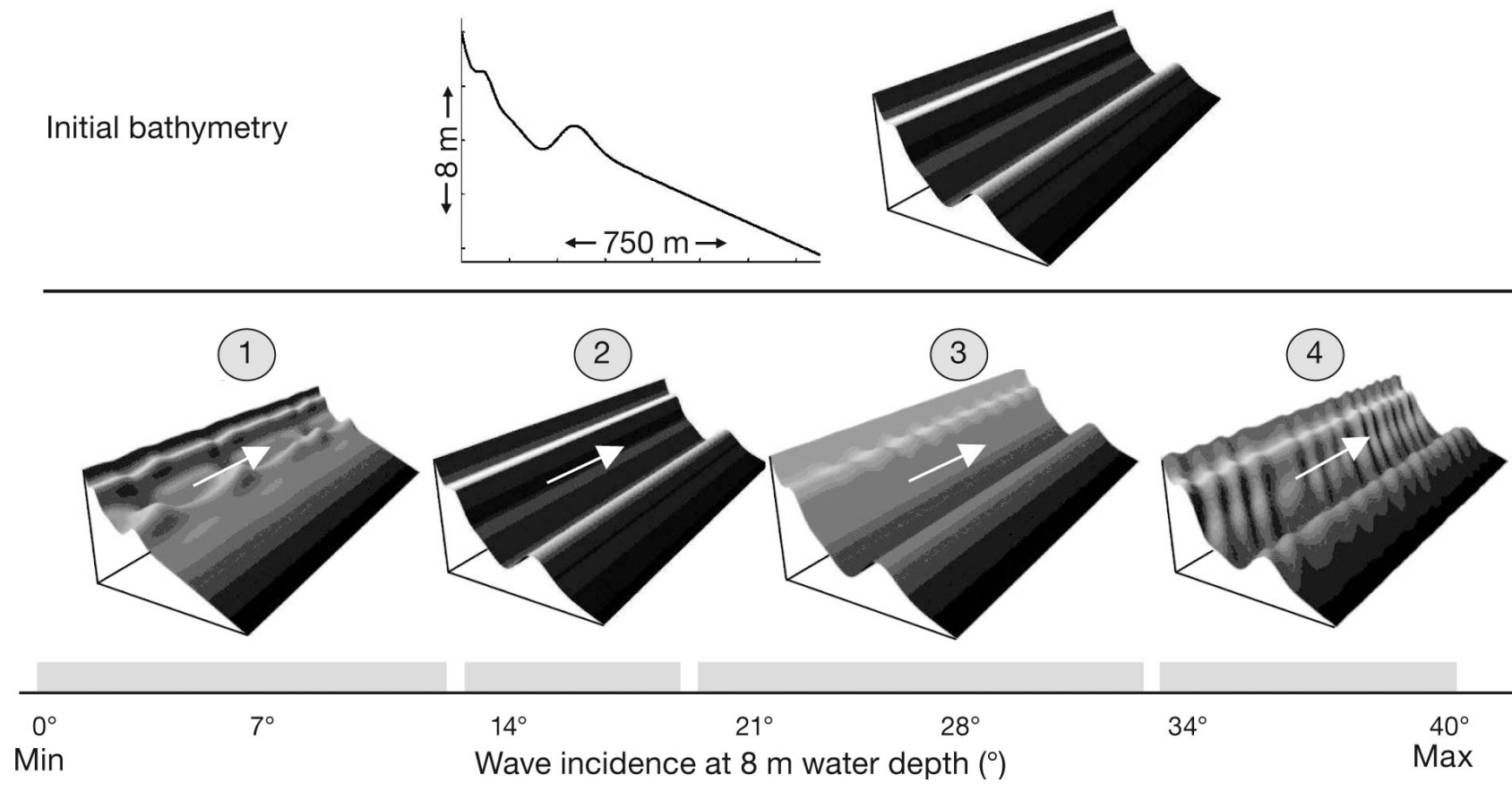

Fig. 9. Initial bathymetry and examples of 3D beach morphologies as a function of wave incidence: (1) crescentic outer bar, and transverse inner bar with rip channels; (2) longshore uniform beach; (3) down-current oriented oblique bars; (4) up-current oriented oblique bars. Adapted from Thiébot et al. (2012) 


\subsubsection{Medium-term / threshold-based modelling}

Following the same idealised approach, the code 1d-morfo was applied (Falqués \& Calvete 2005). This model is able to reproduce the main characteristics of shoreline sand waves, which are undulations of the shoreline with a typical wavelength of several kilometres and time scales of several years (Komar 1998). On the Aquitanian coast, data analysis does not show evidence of such high angle wave instability (HAWI). Within this part of the study, the aim was to explore the potential future development of HAWI along the Aquitanian coast as a result of climate change. The 1d-morfo model was set up using a beach profile corresponding to the longshore averaged Truc Vert bathymetry and typical offshore wave conditions. The results showed (1) the development of shoreline instabilities of very short wavelength (between 500 and $1000 \mathrm{~m}$ ), which is a similar length scale to that of the crescentic patterns; and (2) the presence of shoreline instability for wave incidence $<42^{\circ}$, which was a identified by previous studies (Falqués \& Calvete 2005, Ashton \& Murray 2006a,b). These instabilities also have a much shorter time scale (a few days) than HAWI (a few years). This study does not show evidence of HAWI on a multi-annual scale, but shows that smaller, more rapidly developing shoreline instabilities (low angle wave instability, LAWI; for further details see Idier et al. 2011b), occurring under low wave angles, can potentially form at a number of sites studied by the VULSACO project (Truc Vert, Sète Lido, Dewulf) that were previously thought not to be prone to shoreline instabilities.

\subsubsection{Summary of modelling results}

The models set up for the Truc Vert beach highlight the limitations and uncertainties of the existing nonlinear morphodynamic models to reproduce observations, i.e. to simulate morphological changes for a wide range of wave regimes and on time scales longer than weeks. However, using these models within their range of validity (up-state sequence) to study the beach sensitivity to climate variability scenarios (climate-based approach) allowed the influence of the wave angle direction and wave classes to be identified. By contrast, threshold-based modelling proved useful to identify possible changes of beach behaviour driven by climate variability or future climate change. In this sense, Axis 2 directly contributed to the study of beach vulnerability to climate variability. These studies, by investigating what the system is sensitive to (for example, wave direction), also provided relevant information for practical applications such as the creation of vulnerability indexes.

\subsection{Stakeholder involvement and assessment of mid-term issues}

\subsubsection{Project framework and context}

Fig. 1 shows that, in addition to exposure and sensitivity, vulnerability is related to the adaptive capacity of the system. This capacity is in turn highly related to the involvement of stakeholders as well as their perception of the potential impact of climate change and variability on the system. The purpose of Axis 3 (Fig. 2b) was to understand better stakeholder perception and the decisions they could potentially take to adapt to climate change and variability. This aim is quite modest compared to studies focussing on risk perception based on intensive surveys (Botzen \& van den Bergh 2012), or based on in-depth analysis of risk governance (Deboudt 2012). Here, the approach was restricted to studying the community of stakeholders potentially involved in decisions at the physical scale of the sites, i.e. a few kilometres of coastline.

To understand the background to results obtained for the Truc Vert beach, it is worthwhile outlining the current practice in French governance of coastal zones. This governance is defined by planning at every scale (national, regional, urban and local) and directives (Deboudt, 2012). This is ensured by: the European Union (European level); the French government through the Ministries of Ecology, Sustainable Development, Transportation and Housing (national level); regional councils (regional scale); urban communities; conurbations; communities of communes (inter-communal scale); and communes, i.e. the lowest unit in the French system (local scale). Moreover, over recent years, French policies for coastal planning have evolved considerably under the influence of European policies, which have encouraged, for instance, the management of the coast using an integrated approach (called Integrated Coastal Zone Management, ICZM). In France (Deboudt 2012), the implementation of ICZM pilot projects (between 2005 and 2007) contributed to: building a 'vision of the future' (i.e. a prospective approach); planning at the inter-communal level; taking into account land/sea integration, i.e. jointly taking into account terrestrial and marine concerns (e.g. 
maritime traffic, tourism and fishing) as they interact; resolving use conflicts; and planning at the local level. Results show that future orientation should focus on reinforcing land/sea integration and the appropriation of ICZM issues at the coastal communal scale (Deboudt 2012). Such perspectives were discussed at the French Grenelle Environmental Forums in 2007 and 2009. The forum in 2009 has adopted a climate change adaptation plan, which lasts until 2015. Examples of outputs of this plan, and its contribution to mitigating the effects of climate change on coastal zones, are given by Le Cozannet et al. (2013).

Within this governance framework, and taking account of some of the weaknesses (e.g. the lack of appropriation of coastal risk knowledge and ICZM issues at the communal scale) that have been identified above, the work of the VULSACO project on stakeholders' perceptions and involvement in decision making aims to integrate local, inter-communal and regional scales, at a local decision scale. As stated in Section 2, this work was based on interviews, surveys and decision-making role-play simulations. In the following, we focus on the interviews and role-play simulations for the Truc Vert site, comparing them to results from other sites.

\subsubsection{Interviews and decision-making role-play}

The method used to study perceptions and governance was partly based on scientists' physical knowledge of the sites (observations and modelling), and partly based on the appraisal and analysis of the situation by the stakeholders. Here, we describe how the stakeholders assessments of scenarios of potential effects of future climate change were elucidated.

The methods we used included (1) interviews with local stakeholders, followed by (2) their participation in a group meeting (workshop) where a scenario constructed by the researchers was presented and debated in a decision-making role-play.

Interviews. For the Truc Vert site, 12 local stakeholders were interviewed, including elected representatives, government officials (local, regional and national), members of environmental and residents associations, and business people (camp site owners). These initial interviews helped clarify the following issues:

(1) How the different local institutions cooperate to solve the problems associated with climate change (e.g. erosion). Interviewees knew exactly which institutions to call upon to deal with any specific problem such as erosion or forest damage. Some public areas are state property while others belong to the region (or department), which implies the potential involvement of a significant number of different actors from these institutions.

(2) How the climate is anticipated to evolve over the short and long terms. Participants were concerned about the evolution of the climate in the present and in the future. Present-day concerns include the increased power of winter storms as evidence that climate change is happening here and now. Therefore, local stakeholders framed climate change in terms of climate variability, even though they were not directly questioned on this point. On the other hand, the risk of marine submersion is something that participants considered would arise in the medium or long term.

(3) How local stakeholders would react if erosion and submersion predictions were confirmed. Specifically, the Truc Vert beach participants were not particularly concerned about the possibility of inundation. Some mentioned the natural evolution of the littoral, considering it as a highly dynamic system. Generally, stakeholders described the Truc Vert region as one occupied and used on a seasonal basis. The light structures such as camping sites and parking lots are operational almost exclusively during the summer. The availability of alternative land for these facilities might initially facilitate the choice of strategic retreat in case of erosion and/or submersion, with the underlying attitude as expressed by one stakeholder being: 'we should let nature take its course'. They were much more concerned about threats to inhabited littoral areas close to this beach.

During the interviews, participating stakeholders of all sites answered an individual questionnaire. Three questions were asked to elucidate (1) their personal feeling of involvement with climate change ( $D o$ you feel personally concerned by climate change?), (2) their valorisation of climate change as an issue (Do you consider climate change to be something important for you?) and (3) their perceived capacity to take action in response to climate change (When talking about climate change, do you have the personal feeling that you can do something about it?). Answers ranged from 1 (not at all) to 4 (completely). Fig. 10 shows the results. Stakeholders of the Dewulf site were markedly more concerned about the climate change issue (mean score 3.8 ) than stakeholders from the other sites (mean scores: Truc Vert 3.4; Sète 3.3; Noirmoutier 3.1). The higher mean score at Dewulf could be explained by the fact that the beach is located in an area covered by a regional climate change adaptation plan. 
Stakeholders from all sites assigned equal values to climate change as an issue (Fig. 10) (mean scores: Dewulf 3.8; Truc Vert 3.6; Sète 3.4; Noirmoutier 3.5). This could be explained by stakeholders' common focus on touristic assets at each of the 4 beaches. Regarding their capacity to take action in response to climate change and its effects, stakeholders at Sète Lido were markedly more convinced of their capacity to take action (mean score 2.6) than in the other sites (mean scores: Dewulf 1.7; Truc Vert 2.1 and Noirmoutier 2.2). This is probably a result of the recent and important coastal management work carried out on this site. Focussing on the interview results for the Truc Vert site, it can be noted that the stakeholders interviewed were quite concerned about climate change and considered it an important matter, but were less confident of their capacity to respond to the phenomenon

The interviews also allowed stakeholders to familiarise themselves with the object of research (coastal vulnerability to climate variability) and provided the researchers with an opportunity to explain to each individual what the next step (i.e. the scenario workshop) would be about. During the group activity at the workshop, it became clear that the individual interviews had been a useful preparatory step.

Workshops. Truc Vert was the first site where scenario workshops were conducted, and was the one with the smallest number of participants. The meeting occurred during stormy weather, and some of the invited stakeholders (e.g. the mayor of a nearby town) were mobilised to respond to potential damages and thus could not participate to the workshop. Only 6 stakeholders were able to attend. They represented national, regional and local scales of the governance: Conseil Général de la Gironde, Conseil Régional d'Aquitaine, Direction Régionale des Affaires Maritimes, ONF Sud-Ouest, Secrétariat
Général pour les Affaires Régionales (SGAR), and the environmental association SEPANSO. The decision-making role-play consisted of 3 main phases.

(1) The first phase started with a very brief description of the project in general and of the Truc Vert site in particular. The Truc Vert site was described in its regional context (i.e. the Arcachon Basin and assets) in physical terms, for example the variability of beach volume in relation to the wave climate, and beach evolution during the Johanna event (a storm that hit the Atlantic coast in March 2008; Capo et al. 2008).

(2) After this introduction, the moderator projected participants into the future: they were asked to imagine that they were in 2030 (second phase). This procedure has the advantage of softening all the possible tensions or conflicts that could arise between stakeholders. Then, scientists outlined a fictive, yet plausible storm event occurring in 2030. To introduce this fictional scenario, we presented (unidentified) photographs of the damage caused by the storm Xynthia in February 2010, which caused severe erosion and submersion. During the scenario presentation, participants were also shown maps of water level (tide and storm surges) and waves during this fictive event. The offshore conditions described were only slightly more severe than those observed during the Xynthia event. Finally, participants were shown fictive cross-shore profiles as well as evidence of a $25 \mathrm{~m}$ coastline retreat and dune breaching. Then the scientists left the meeting-room, and the moderator distributed 2 prepared newspaper articles, written in a journalistic style, based on the fictive storm scenario. Some further maps (e.g. of assets) were also provided. These presentations of the physical setting provided a grounding to trigger group discussions. The task of the group was to provide, by the end of the session, a proposal for how such storms occurring in energetic periods (within the climate variability scale) should be dealt with within the governance process.

(3) The third phase consisted of a debriefing in which participants and researchers informally discussed the experience of the workshop. The end of this last phase closed the workshop.

Workshop results and discussion. Outputs of the workshop demonstrated participants' awareness and concern about the effects of the storm event and the media's representation of the consequences for the local economy. It is possible that the Xynthia event, which occurred only a
Fig. 10. Stakeholder perceptions of climate change at the 4 study sites in response to a questionnaire: (a) personal involvement with the issue; (b) valorisation of the issue; (c) perceived capacity to take action. Scores range from 1 ('not at all') to 4 ('completely'). SETE: Sète Lido; TV: Truc Vert; LT: La Tresson; DW: Dewulf 
few weeks before the workshop, might have contributed to their awareness of the risks to coastal areas posed by storm events of this kind and familiarity with how they are depicted by the media at the national level. As a strategy to address this issue, the stakeholders focussed on communication to reassure tourists all over the country that the affected beaches would be fully restored. For example, one of the participating stakeholders mentioned that 'here is where expertise is important, not only to understand the effects of the phenomenon, but also concerning all that will it be necessary to do in terms of rehabilitation and rebuilding installations, reception facilities and so on'. From this, it seems clear that the main concern of the stakeholder group was to repair the damage that followed the 2030 storm. The climate change issue, as the underlying cause of the situation they had to face in the storm scenario, was very rarely mentioned. This observation seems at odds with the results of the questionnaire answered by participants during the interview phase, which revealed very high levels of concern and involvement of stakeholders with the climate change issue in general (Poumadère et al. 2010). Considering the importance of climate change and variability in their daily activities, and the weight participants previously attributed to it, not mentioning the subject in the group session could indicate individual resistance to discussing a phenomenon perceived as threatening to the safety of their neighbourhood, community and emotionally meaningful places (Lima 1998). Another reason for this avoidance could have been the belief that the national government (or even some international body) is the entity mainly in charge of climate change policy, leaving local communities with little or no control over policies or their implementation. A last explanation for this avoidance could be that even if they perceived it as a threat, they felt the climate change context was clear, and in this situation they were just responding to a single event within the larger context of climate change.

The group deliberation during the scenario workshop revealed that this particular local community would not, if predictions of submersion and erosion damage actually came true, invest in major changes to their environment. Changes would basically focus on the following summer season, especially in terms of the image of the locality disseminated to the rest of the country. This suggests that, at the local level and in this particular region, human action will not reduce the vulnerability of coastal areas but will mainly respond to damage caused by climate change and variability.
The role-play simulations shed some light on the psychological relationship of local populations to coastal threats and vulnerability at decadal time scales. Participants considered the scenarios to be realistic and appropriate. Framing the scenario in 2030 made it possible for them to consider and discuss issues that, although they are understood in general terms, are difficult to conceive of in present conditions (e.g. strategic retreat). We noted that, when questioned about the predicted life span of coastal defence works, stakeholders considered 20 to $30 \mathrm{yr}$ to be acceptable. Alongside this apparent realism, an emotional response was observable when participants were exposed to evidence of the damage caused to their territory. In their review of studies of the psychological consequences of temporal distance, Trope \& Liberman (2003) showed how people construct different representations of the same information depending on whether it pertains to the near or distant future. Information about distant future events is associated with what they call 'high-level construals', which are abstract, decontextualised and general information. Information about near-future events is associated with 'lowlevel construals', which are concrete, contextualised and specific information. Long-term future situations, such as environmental threats, are often representated as high-level construals (Trope \& Liberman 2003), since they contain very few elements of concrete experience. This conceptualisation is of central importance for decisions about climate change and variability and the threats they pose: decisions about effects felt in the future (high construal level) will depend on decisions taken today (low construal level). In this sense, the workshop situation brought the distant future to the 'here and now', allowing the consideration of information about the distant future at a low construal level. These construals became instrumental, at least to the extent of facilitating some group consensus in the decision-making process. The extent to which this effect will last and develop outside of the workshop situation remains to be studied. However, there are costs associated with this psychological effect. Besides the material costs of organising the workshop and developing the scenario, there is the human cost of confronting people with negative future visions of their territory, or with what they do not want to know. Researchers using this scenario method ought to be ethically sensitive to this issue.

Another insight about perceived vulnerability relates to stigmatisation. The Truc Vert participants appeared aware and concerned about the media re- 
porting of the storm event. Clearly, they wanted to attenuate the stigmatisation effect produced by media reports and images of a devastated area. To address this issue and limit the impact upon local economy, they put forward communication strategies aiming to reassure tourists from all parts of the country that all affected beaches areas would soon be totally reconditioned. From the workshop experience, it is clear that the notion of a 'retreat' is known and is considered a possible solution. Nevertheless, even if individual participants advocate this solution, the group as whole agrees in considering the retreat option as too radical.

\section{VULNERABILITY INDEXES FOR SANDY BEACHES}

Coastal management requires the use of vulnerability indexes to help the decision-making process. These indexes have many uses, such as for instance the prioritisation of human intervention, analysis of what makes the system vulnerable, or in surveying the temporal evolution of this vulnerability. Furthermore, in the development of indexes for a selected environment, it is fruitful to base the analysis on several sites, and to start out by investigating the capacity and limits of existing indexes at these sites. For these reasons, the development of a vulnerability index for sandy coasts is presented here as a single process, integrating application of existing indexes and development of new ones, with reference to the 4 sites studied by the project.

\subsection{Existing vulnerability indexes: application and limits}

For the development of vulnerability indexes for sandy coasts, we first analysed and applied existing indexes developed for this purpose in order to better identify their limitations for application to sandy coasts. This limitation analysis was based on the physical knowledge of the sites acquired from the results of data analysis and modelling, which allowed the main behavioural traits and drivers of the system (e.g. wave direction for the Truc Vert site) to be identified. Furthermore, knowledge of the risk management practices for each site was used to determine whether the main characteristics of the intervention (i.e. strategy of hard defence [e.g. groynes], soft defence [e.g. beach replenishment], retreat) are taken into account or not in the existing index.
Apart from emerging probabilistic approaches (e.g. Guttiérrez et al. 2010, Yates \& Le Cozannet 2012), there are 2 main types of vulnerability index: one focussing on the vulnerability of sandy coasts to storms, i.e. a short time scale (e.g. Dal Cin \& Simeoni 1994, Sallenger 2000); the other on longer time scale vulnerability of any type of coast, mainly to erosion (e.g. Gornitz et al. 1994, Coelho et al. 2006, Hemer 2009). These indexes take into account climate dependant variables such as waves. In the present study, we focussed on erosion and on time scales of years to decades, and thus mainly on the second type of vulnerability index. The index of Hemer (2009) is interesting because it takes account of variations in longshore sediment transport. However, its application requires knowledge of the wave characteristics at several locations along the coast. Such data are not always available and this makes the application of such an index difficult if one wants to use it on various sites. The indexes of Gornitz et al. (1994), also called coastal vulnerability indexes (CVI), and Coelho et al. (2006) are quite similar. The main difference is that the index of Gornitz et al. (1994) takes sea-level rise into account, whereas the index of Coelho et al. (2006) is focussed on anthropogenic impacts. The application of the Gornitz et al. (1994) indexes showed that they hardly discriminate between the 4 study sites. Only one of the indexes (CVI-6) shows that the Sète Lido is the most vulnerable site; none show the reduced vulnerability of Sète Lido following the implementation of a coastal management project (see below). Thus, among the indexes of Gornitz et al. (1994), Coelho et al. (2006) and Hemer (2009), the Coelho et al. (2006) index was chosen as the existing 'medium-term index' best suited to the VULSACO project's objectives.

This index is designed for application at annual to decadal time scales and ranges from 1 (low) to 5 (high vulnerability). More precisely, Coelho et al. (2006) proposed 3 indexes, based on the same parameters, but using different weightings. The input parameters of these indexes take account of the general characteristics of the beach (Table 3): historical erosion (EA), tidal range (TR), maximal wave height (WH), topographic elevation (TE), geology (GL), geomorphology (GM), ground cover (GC), and distance from an urban front or a structure to the shoreline (DS). In contrast to indexes like the CVI (Gornitz et al. 1994), they also take the influence of human factors into account (anthropogenic factor AA, Table 3). Coelho et al. (2006) proposed 3 weighting methods (W1, W2 and W3) for the parameters (Table 3). W1 gives an equal weight to all the param- 
Table 3. Left: parameters of vulnerability indexes developed by Coelho et al. (2006), and weightings assigned to indexes W1, W2 and W3. Right: observations and parameter values for the Truc Vert site, on a scale of 1 to 5, from lowest to highest vulnerability. The index values are given in Table 4

\begin{tabular}{|c|c|c|c|c|c|c|}
\hline \multirow[t]{2}{*}{ Parameter } & \multicolumn{4}{|c|}{ Coelho et al. (2006) indexes } & \multicolumn{2}{|c|}{ Application to Truc Vert beach } \\
\hline & Acronym & W1 & W2 & W3 & Observation & $\begin{array}{l}\text { Parameter } \\
\text { value }\end{array}$ \\
\hline Erosion/accretion rate & EA & 1 & 1 & 3 & Small accretion & 1 \\
\hline Tidal range & TR & 1 & 1 & 2 & $3.6 \mathrm{~m}$ & 3 \\
\hline Highest class of significant wave height $\left(H_{\mathrm{s}}\right)$ & WH & 1 & 1 & 5 & $5.75 \mathrm{~m}$ & 3 \\
\hline Elevation to chart datum & $\mathrm{TE}$ & 1 & 1 & 7 & $5-20 \mathrm{~m}$ & 3 \\
\hline Geology & GL & 1 & 2 & 9 & $\begin{array}{l}\text { Nonconsolidated } \\
\text { fine sediment }\end{array}$ & 5 \\
\hline Geomorphology & GM & 1 & 1 & 4 & Dunes & 5 \\
\hline Ground cover & $\mathrm{GC}$ & 1 & 1 & 1 & Ground vegetation & 2 \\
\hline Distance of urban front (or structure) to the shoreline & DS & 1 & 2 & 8 & $>1000 \mathrm{~m}$ & 1 \\
\hline Anthropogenic factor & AA & 1 & 1 & 6 & Shoreline stabilisation & 1 \\
\hline
\end{tabular}

eters. In W2, GL is the most important parameter. W3 decreases the relative importance of GC and TR in comparison with the other parameters.

The indexes of Coelho et al. (2006), when applied to the 4 sites considered in this study, revealed a vulnerability hierarchy among the sites (Table 4) that was consistent with knowledge of the sites. It should be noted that 2 evaluations were conducted for Sète Lido. A large management project (comprising road retreat, dune profiling, beach replenishment, among other interventions) was undertaken recently at this site, led by the Thau Basin Agglomeration Commu-

Table 4. Values of vulnerability indexes developed by Coelho et al. (2006) (W1, W2 and W2) and by the present study (SCVI-1 and SCVI-2), normalised on a scale of 1 to 5, from lowest to highest vulnerability. W1, W2 and W3 are indexes with the different weightings shown in Table 3. SCVI1 and SCVI-2 are indexes including and not including parameter values for human intervention, respectively. For the Sète Lido site, 2 configurations were considered to study the effects of a recent large coastal management project on vulnerability at this site: 'Sète (old)' and 'Sète (new)' correspond to the beach system before and after the management project, respectively

\begin{tabular}{|lccccc|}
\hline \multirow{2}{*}{ Site } & \multicolumn{5}{c|}{ Index values } \\
& $\begin{array}{c}\text { Coelho et al. (2006) } \\
\text { W1 }\end{array}$ & W2 & W3 & This study \\
& SCVI-1 & SCVI-2 \\
\hline Sète (old) & 3.3 & 4.0 & 3.7 & 4.0 & 4.0 \\
Sète (new) & 2.9 & 3.5 & 3.2 & 3.7 & 4.1 \\
Truc Vert & 2.7 & 3.1 & 2.8 & 2.5 & 2.2 \\
La Tresson & 2.6 & 2.9 & 2.7 & 3.3 & 3.1 \\
Dewulf & 2.7 & 3.0 & 2.7 & 3.4 & 3.2 \\
Range of index & 0.6 & 1.0 & 1.0 & 1.5 & 1.9 \\
$\quad$ values & & & & & \\
\hline
\end{tabular}

nity. Accordingly, indexes were computed for the site before and after this management project. The results showed that Sète Lido before the management project ('Sète old') was the most vulnerable site. Sète Lido after the management project ('Sète new') had a lower vulnerability index, but was still the most vulnerable of the 4 sites. The 3 other sites were characterised by similar vulnerability values (Table 4 ). However, the difference between vulnerability index values between the least (La Tresson) and the most (Sète old) vulnerable sites was small: about 1 on a scale of 5 . This result can be explained by the fact that the geomorphologic characteristics of the sites are similar (sandy beaches), whereas the methodology of Coelho et al. (2006) is designed to compare a broader range of coastal types, including for instance cliffs, marshes or beaches. In order to better differentiate the vulnerability between beaches and also to provide information regarding impact of climate variability, a new vulnerability index is proposed.

\subsection{A vulnerability index for sandy coasts (SCVI)}

In developing a new vulnerability index, firstly we concentrated on building an index of spatial vulnerability in order to be able to make comparisons among sites. Secondly, we investigated how this index could be used to investigate the effects of climate variability.

The construction of the Sandy Coast Vulnerability Index (SCVI) involved 4 main steps: first the identification of principal categories (classes) of parameters influencing beach vulnerability; second the identification of the parameters themselves; third, the ag- 
gregation of the parameters; and finally the weighting of categories (Fig. 10).

Similar to the procedure of Martínez et al. (2006) in the design of indexes of dune vulnerability, we identified 5 main categories: geology/geomorphology (GEO), marine influence (MAR), anthropogenic destabilisation factors (DES), anthropogenic stabilisation factors (STB) and historical displacement (HID). These categories are slightly different compared to those of Martínez et al. (2006), which include aeolian transport, but reduce human intervention to only one class. Our HID category corresponds to the EA parameter of Coelho et al. (2006).

Next, for each category, parameters were identified, such that: (1) the parameter values ranged from 1 (very low vulnerability) to 5 (very high vulnerability) for a sandy coast environment, (2) all the parameters identified as important for the vulnerability characterisation of sandy coast were taken into account. Table 5 and Fig. 11 show the categories and associated parameters; Table 5 provides details of the calculation of parameter values on the 1 to 5 scale.

Table 5. Categories and parameters of the SCVI vulnerability indexes and definitions of parameter values (see Fig. 11 for explanations of abbreviations of categories and parameters). Square brackets: [a-b] means the parameter range includes a and $b_{;}$] $\left.a-b\right]$ means the range excludes $a_{i}[a-b[$ means the range excludes $b$. NC: not considered, i.e. the parameter cannot be given because of the vulnerability scale of the considered parameter (this applies when a parameter can take only the values 1, 3 or 5, and not 2 and 4 )

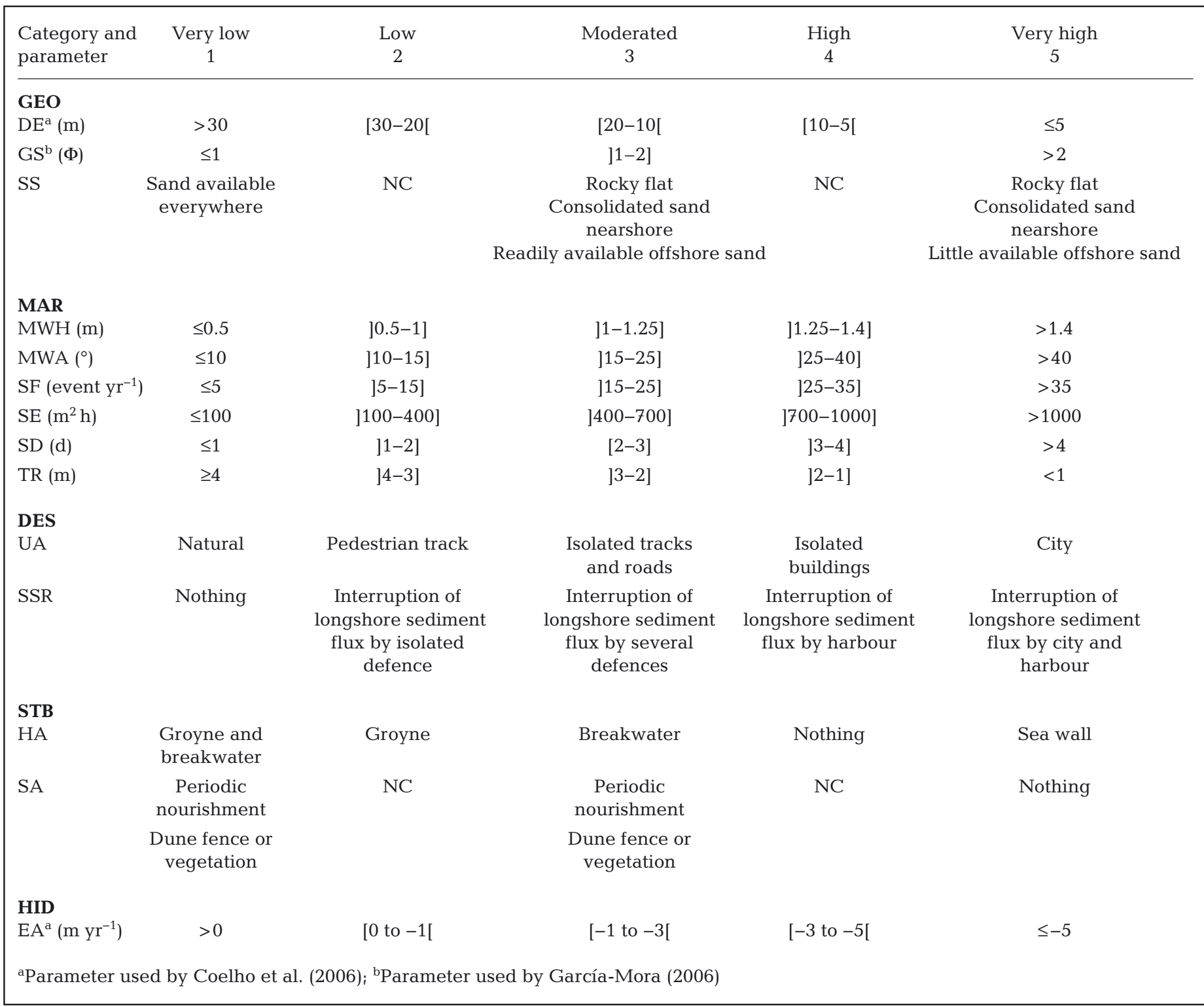


Within the GEO category, 3 parameters were identified as important for vulnerability to erosion, based on knowledge of the sites (Axis 1): dune elevation (DE), grain size (GS) and the sedimentary stock (SS). Here, DE is similar to the TE parameter of Coelho et al. (2006), but adapted to sandy coasts, measuring dune elevation above the highest tide, rather than topographic elevation above a chart datum reference. The GS parameter is computed using the GS $\phi$ unit, as in the García-Mora et al. (2001) index. The SS parameter is estimated by expert judgement. For the MAR category, instead of using only maximal wave height to characterise the wave action, we distinguished 2 main types of wave actions, as results of Axes 1 and 2 showed different beach dynamics occurring depending on wave conditions (event and year scale). The first type of wave action is related to the longshore sediment transport induced by mean wave climate. This action is described by the mean annual wave height (MWH) and the mean annual wave incidence angle (MWA). The second type of wave action is more related to energetic events (storms) inducing either erosion or submersion. This is characterised by the mean occurrence of storms $(\mathrm{SF})$, their duration (SD) and their energy (SE), with energy defined as the integral of the square wave height during storms. The storm can be defined using different approaches. In the present study, for instance, the POT (peak over threshold) approach was used (see e.g. Pickands 1975). It is worth drawing attention to the effect of TR on the wave action. Assuming a storm occurring during $1 \mathrm{~d}$, the shoreline erosion effect should be larger for an environment with a small tide than one with a larger tide. Indeed, for tidal environments, the waves will modify the shoreline mainly during high tide, and thus only during a fraction of the full day of storm, contrary to what would happen for an environment without tide. Thus, TR is also taken into account, with vulnerability decreasing with TR. Regarding the human impact on the vulnerability of sandy beaches, 2 categories were distinguished based on knowledge of the sites and of direct and indirect coastal management practices (Axes 1 and 3). The first category (DES) takes account of indirect perturbation of the natural system by human presence, for instance due to induced sediment reduction (SSR) or to urbanisation (UA). The second category (STB) takes account of 'direct' anthropogenic actions aimed at reducing vulnerability, distinguishing between soft (SA) and hard (HA)
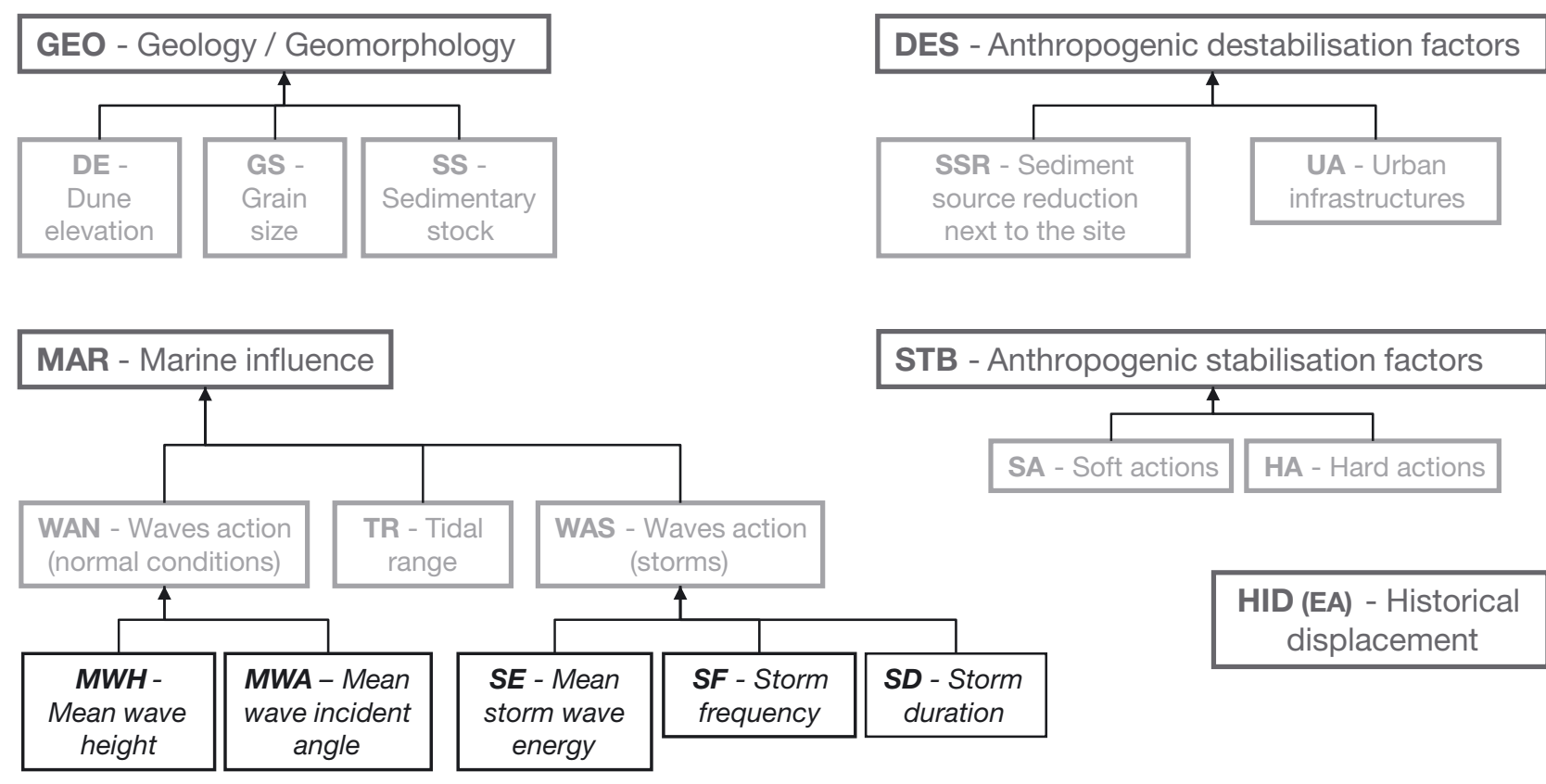

HID (EA) - Historical displacement

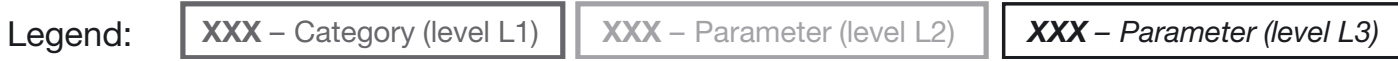

Fig. 11. Schematic representation of the 3-level hierarchy used to structure the vulnerability indexes: category level (L1, dark grey); first parameter level (L2, light grey); second parameter level (L3, black) EA: historical erosion category used by Coelho et al. (2006), equivalent to HID in our indexes 
actions. Finally, the category related to historical displacement was represented by a single parameter, corresponding to the erosion rate (EA) parameter of Coelho et al. (2006).

The next step was to assign weights to the parameters. Fig. 11 shows that the indexes are structured in a 3-level hierarchy: the category level (L1), a first parameter level (L2) and a second parameter level (L3). From L3 to L2, as well as from L2 to L1, simple averages are calculated: for example, the WAS parameter (level L2) is obtained by averaging the three parameters SE, SF and SD (level L3). This leads to 5 values (one per category) characterising different aspects of the vulnerability of sandy beaches. Finally, the 5 values are aggregated to provide a single value. Several weighting techniques exist, derived either from statistical models, or from participatory methods (OECD 2008). In the present study, there was not enough data to perform proper statistical analysis. Instead, the weightings were chosen based on expert opinion, such that the the GEO and DES categories were given the highest weight (2), and MAR has a weight of 1 . The inclusion of STB in the index should be optional, depending on whether there is a need to characterise the 'complete' vulnerability of the site or vulnerability without human intervention. If STB is taken into account, then its weight is equal to 1 . The category HID has a weight of zero. The reason for this is that this category, physically, is the result of the other ones (historical shoreline displacement is related to the geology, geomorphology, wave action, tidal range and human action). Thus, the category HID is mainly informative, for stakeholders. Finally, 2 single value indexes (SCVI-S) were calculated: one with (SCVI-1) and one without STB (SCVI-2). Table 4 shows the results for the 4 study sites (site-specific results are discussed later on) and illustrates the improved characterisation of the vulnerability of sandy beaches possible by the new indexes, shown by the wider range of index values, indicating a more discriminating index for sandy coasts.

However, such single value indexes do not provide information on what makes the system vulnerable and how human action could modify this vulnerability. Thus, in preference to integrated values, we preferred to use a visualisation which allowed the contribution of each category to the beach vulnerability to be identified. A radial visualisation is an efficient assessment tool (Fig. 12, top). This radial format multi-value index (SCVI-R) clearly shows, for each site, the major causes of vulnerability and the influence of human actions in decreasing or increasing
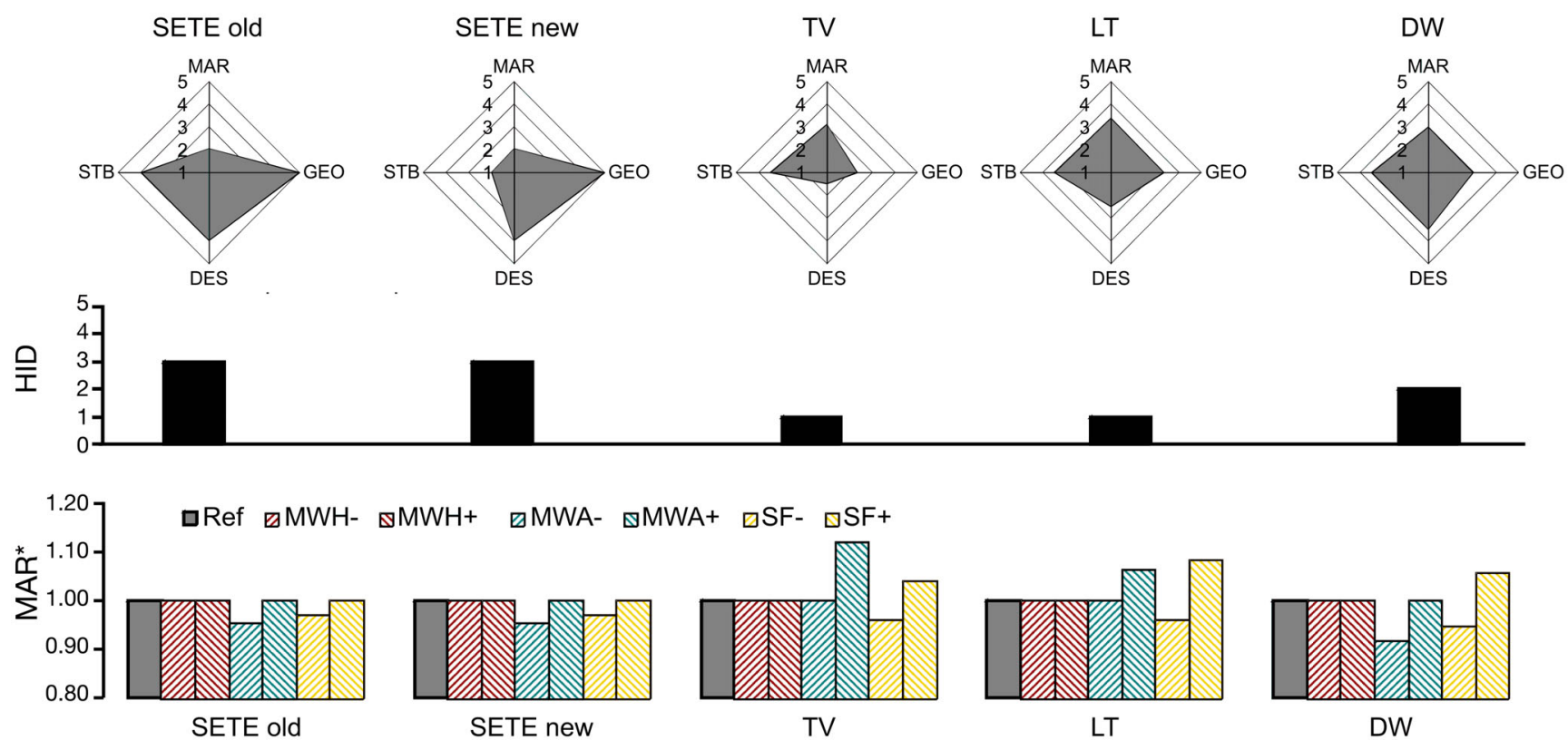

Fig. 12. Vulnerability at the 4 study sites, based on the SCVI indexes. SETE: Sète Lido; TV: Truc Vert; LT: La Tresson; DW: Dewulf. Results for 'SETE (old)' and 'SETE (new)' are for the beach system before and after the management project, respectively. Top: radial visualisation of SCVI-R. Centre: historical displacement (HID) parameter values. Bottom: variation in values of the dimensionless marine influence category (MAR*), showing reference values (Ref, which is equal to 1 , since MAR* is made dimensionless using this reference value) and values for 6 climate variability scenarios, corresponding to positive and negative changes to selected parameter values. Abbreviations of categories and parameters are given in Fig. 11 
vulnerability. The vulnerability of the site is directly proportional to the surface of the radial graph: the larger the surface, the more vulnerable the site.

The 3 indexes presented above allow ranking of the vulnerability of the study sites. We also investigated how these indexes can be used to analyse the extent to which the vulnerability is sensitive to climate variability based, in the first instance, on results from the Truc Vert site. One approach is to set up scenarios based on climate variability characteristics (i.e. the induced wave and surge variability), as was done for the model simulations (Axis 2). However, variations of $10 \%$ in the wave characteristics (e.g. $\mathrm{MWH}$ and SE), i.e. values consistent with the known climate variability, were too small to induce a change in any of the indexes. Thus, these types of index cannot be used to investigate the impact of climate variability/change on vulnerability. As an alternative, to estimate the impact of climate on variability, we concentrated on the category MAR, since it is directly influenced by climate variability. We calculated dimensionless marine influence (MAR*) by dividing the value for MAR by the reference value (i.e. the value obtained by analysing wave data over over the last decade, which are also the values used to compute the SCVI-S indexes shown on Fig. 12 [top] and Table 4). For the present study, we defined scenarios of climate variability, based on the assumption that TR is not influenced by climate variability, such that only the long and short-term marine hydrodynamic wave conditions were taken into account. We also considered scenarios where SE and SD remain constant, such that only variations in $\mathrm{MWH}$, MWA and SF are represented. The climate variability scenarios were based on a 'one-at-a-time' approach, with variations in $\mathrm{MWH}$ of $\pm 10 \%$, in MWA of $\pm 10^{\circ}$, and in SF of $\pm 50 \%$. Such values are chosen based on the order of magnitude of variations in wave characteristics over the period 1958 to 2001 in the Bay of Biscay (Charles et al. 2012a). Fig. 12 (bottom) shows the temporal variability of the MAR* category for every site for the above climate variability scenarios.

\subsection{Site application and use for coastal management}

The application of the SCVI indexes to the 4 sites provides comprehensive knowledge of the sites' vulnerability. The SCVI-2 index (Table 4), which does not take STB into account, confirms the vulnerability ranking among the sites: Sète Lido is the most vul- nerable site whereas Truc Vert is the least vulnerable. This vulnerability ranking is in agreement with knowledge of the sites (Axis 1). The vulnerability ranking is the same if STB category is taken into account (SCVI-1). The SCVI-R radar visualisation allows more in-depth vulnerability analysis. Indeed, Fig. 12 (top) shows, for instance, that a major cause of vulnerability at Sète Lido is the geology and geomorphology (related to the lack of sediment in the area). Comparison between values for SETE old and SETE new in Fig. 11 (top) shows the effects of the management project, which reduced the vulnerability of the system. Indeed, the main categories which can induce a change in the index and can occur over a realistic time span are the anthropogenic actions (aggravating or stabilising). For instance, for the Dewulf site (Fig. 2b), urbanisation with buildings (i.e. UA 4, instead of 2), combined with a halt to vegetation defence measures (i.e. $\mathrm{SA}=5$, instead of 3 ) would lead to increased values of the parameters DES and STB, such that the resulting vulnerability to erosion would be greater than at Sète Lido. Thus, we foresee that the vulnerability index could be of use for the spatial analysis of vulnerability (hot-spot identification) or estimating the relative influence of human action.

Regarding the sensitivity of vulnerability to climate variability, the MAR* category provides qualitative information (Fig. 12, bottom). Considering only changes in MWH, MWA and SF, Sète Lido would be the least sensitive site to climate variability, whereas Truc Vert beach would be the most sensitive. Furthermore, the study sites would be less sensitive to changes in mean wave height (MWH), than to changes in mean wave angle (MWA). This result is in line with some of the modelling results.

\section{DISCUSSION: LESSONS AND OUTLOOKS}

The VULSACO project aimed to provide methods and results to assess the vulnerability of sandy coasts to climate variability, on a local scale. A number of lessons can be learned from the $3 \mathrm{yr}$ project.

The main aim of the project was to estimate the vulnerability of sandy coasts, with the final objective being to develop and apply vulnerability indexes. A lesson of the project is that it is beneficial for such vulnerability indexes to be developed based not only on existing indexes but also on results of morphodynamical analyses and inputs from scientists with an in-depth knowledge of the study sites. This approach facilitates evaluation of the validity of existing in- 
dexes for the studied sites, and provides knowledge for the development of new indexes able to hierarchise the vulnerability of sandy beaches. However, even significant hydrodynamic modifications related to climate variability (e.g. variations of wave height of $10 \%$ ) did not cause significant changes inthe index values. In this sense, modelling complements the use of vulnerability indexes: while the indexes enable spatial analysis of vulnerability, the potential impact of human intervention, and the temporal evolution of the erosion rate, the models provide information on the sensitivity of the beach to potential changes in marine parameters (related for instance to climate variability or climate change).

The VULSACO project was based on the study of sites where a minimum of data and knowledge was available. It made use of existing data over a decadal time scale. However, a decade is still a quite short period of time to study the impacts of climate variability. As a final lesson, it should be noted that estimating indexes requires input data, both to estimate parameter values, and to assign weightings for the construction of indexes. The more sophisticated the index or the model, the more data are required. This last point highlights the need for observations, continuous measurements and open-access databases, especially as inputs for the assessment of effects of climate variability impacts on a decadal time scale, but should also encourage the development of indexes making use of basic parameters which could be available for most of the coastline within the next decade, and not dependent on very precise and refined data.

In overall terms, most of the initial objectives of the project were reached, i.e. (1) analysis of stakeholder perceptions and decisions that stakeholders could potentially take in response to risks associated with climate change and variability, (2) development of vulnerability indexes for sandy beaches. The vulnerability of sandy beaches to climate variability was mainly elucidated based on data analysis and modelling, whereas the sensitivity to anthropogenic actions was assessed based on analysis of stakeholder perceptions and the development of indexes. The objective of characterising the sensitivity of beaches to climate variability was only partially achieved due to the complexity of the sites (e.g. related to scarce sedimentary resources and strong anthropogenic influence, as at Sète Lido) and/or lack of long-term data. A number of challenges remain for the study of vulnerability of sandy beaches. Even if the results obtained with the morphodynamical models provided useful information for understanding the beach system and also for developing the indexes, these mod- els do not properly simulate beach dynamics under energetic events (storms). It should be noted that numerical modelling of sandy beaches is a rather young discipline, but that the morphodynamic modelling community has made major scientific advances in recent years, especially in the development of short-term models (e.g. Roelvink et al. 2009). This type of model will eventually provide fruitful information on the sensitivity of sandy beaches to climate variability, on times scales of a few years to decades. In addition, the VULSACO project contributed to the development of vulnerability indexes for sandy coasts. However, these indexes now need to be tested and applied to other sandy beach environments. As a final research output of the project, informal scientific discussions highlighted the importance of thresholds for stakeholders. This led to the idea of extending the threshold-based modelling approach (Axis 2), to a risk threshold-based approach (Cunderlink \& Simonovic 2007, Idier et al. 2012, Rohmer \& Idier 2012). This approach uses a level of hazard or damage considered as acceptable by society (input), and provides the associated return period (output). Such a method could help identify risk reduction interventions, i.e. adaptation measures, as well as; contributing to risk assessment updates in a context of climate change.

The risk threshold-based approach development is an example of ideas emerging from discussions between stakeholders and scientists. The project used an interdisciplinary approach, developed at a local scale, establishing links between researchers and stakeholders. This provided opportunities for researchers to identify the needs and worries of the stakeholders, and to transfer knowledge acquired by the project to stakeholders, encouraging adaptation. This type of approach can be considered as 'boundary management', in the sense it contributes to manage boundaries between expertise and decision making by more effectively linking knowledge to action. (Cash et al. 2003). Several knowledge transfer tools were used by the project. For knowledge transfer between scientists, the tools used were mainly scientific presentations and meetings, either focussed on one site and addressing all the axes (i.e. all the disciplines involved), or across sites, focussed on one discipline (e.g. modelling, Axis 2). This intra-team knowledge transfer was stimulated by collaborative work on site, gathering together geographers, geologists, physicists, modellers and sociologists, all working towards a common end. It was also favoured by the application of different models by different modellers on the same site (Axis 2), the use of scenarios 
(Axes 2 and 3), and the discussions to identify the driving parameters at each site (Axis 4). Knowledge transfer between stakeholders and scientists was mainly achieved through the interviews, questionnaires and decision-making role-play (Axis 4). In the interviews and questionnaires, knowledge transfer was mainly from stakeholders to scientists. In the decision-making role-play, there was a 2 -way transfer, with scientists bringing information on presentday site vulnerability and possible future scenarios, and stakeholders helping scientists to better understand their perceptions, constraints on action, existing resource usage conflicts, and decision-making options. In this decision-making role-play, each scenario was presented as far as possible as a complete story (storms arriving, wave height and water level increasing, erosion and submersion happening, damage caused); this storytelling approach is an efficient way to transfer knowledge (Hallegatte et al. 2011). Knowledge was also transferred from project scientists to other scientists, through the project's contribution to the organisation of a workshop on climate change impact of coastal risks (BRGM 2010). Finally, there was a knowledge transfer from the project toward the public through its website, and reports on local TV and radio, as well as in regional and national newspapers (e.g. Le Monde), thanks to the interest of journalists in the project.

\section{CONCLUSIONS}

The VULSACO project aimed at an integrated analysis of the influence of climate variability and human action on the vulnerability of sandy beaches for the period 2010-2030. The method was mainly based on local data analysis, numerical modelling and analysis of stakeholder perceptions. The time period considered was appropriate for study of the influence of climate variability on sandy beaches and to help stakeholders understand the potential effects of climate change and extreme events. In addition to improved knowledge of the system (e.g. hydrodynamic and morphodynamic processes, governance), the variabilities in beach volume was identified in relation to wave energy, in particular for Truc Vert beach. Results of data analysis and modelling led to the identification of new parameters for use in vulnerability indexes, including the angle of wave incidence, availability of sedimentary resources and human impacts. These parameters were incorporated in a new vulnerability index, SCVI, designed for sandy beaches and focussed on erosion and a decadal time scale. This index now needs to be tested on other sites. The analysis of governance contributed to an improved understanding of social representations of the issue, as well of stakeholders' decision-making options. Prominent among these options were strategic retreat and communication. The use of fictive scenarios at the 2030 horizon with different roles played by stakeholders allowed the integration of stakeholders in the vulnerability analysis. The remarkable level of engagement of stakeholders is worth highlighting. This was probably partly due to the interdisciplinary approach that provided scientific background for stakeholders, and allowed them to play a role in the project.

Acknowledgements. The VULSACO project (No. ANR VMC06-009) was financially supported by the Agence Nationale de la Recherche (ANR), through the VMC program. BRGM and CARNOT are acknowledged for providing funds allowing the completion of this study. We are grateful to the ECORS'08 project for contributing to field measurements taken on the Truc Vert beach.The Polytechnic University of Catalonia, the Administrative Community of Noirmoutier and stakeholders also participated in the work of the project. The authors thank Marissa YatesMichelin, Thomas Bulteau and local stakeholders for their contribution to the present work.

\section{LITERATURE CITED}

Adger NW, Kelly M, Bentham S, Eriksen S (2004) New indicators of vulnerability and adaptive capacity. Report No. 7, Tyndall Centre for Climate Change Research, Norwich

Allard J, Bertin X, Chaumillon E, Pouget F (2008) Sand spit rhythmic development: a potential record of wave climate variations? Arçay Spit, western coast of France. Mar Geol 253:107-131

Allen Consulting (2005) Climate change risk and vulnerability: promoting an efficient adaptation response in Australia, final report. Australian Greenhouse Office, Department of the Environment and Heritage, Canberra

- Almar R, Castelle B, Ruessink BG, Sénéchal N, Bonneton P, Marieu V (2010) Two- and three-dimensional doublesandbar behaviour under intense wave forcing and a meso-macro tidal range. Cont Shelf Res 30:781-792

Ashton A, Murray AB (2006a) High-angle wave instability and emergent shoreline shapes. 1. Modeling of sand waves, flying spits, and capes. J Geophys Res 111: F04011. doi:10.1029/2005JF000422

Ashton A, Murray AB (2006b) High-angle wave instability and emergent shoreline shapes. 2. Wave climate analysis and comparisons to nature. J Geophys Res 111:F04012. doi:10.1029/2005JF000423

Botzen WJW, van den Bergh JCJM (2012) Risk attitudes to low-probability climate change risks: WTP for flood insurance. J Econ Behav Organ 82:151-166

BRGM (ed) (2010) Recueil des actes du colloque des 
'Journées impact du changements climatique sur les risques côtiers' (workshop proceedings). Orléans, 15-16 Nov 2010. BRGM, Orléans, www.brgm.fr/content/ journees-impacts-changement-climatique-sur-risquescotiers

Brivois O, Idier D, Thiébot J, Castelle B, Le Cozannet G, Calvete $\mathrm{D}$ (2012) On the use of linear stability model to characterize the morphological behaviour of a double bar system. Application to Truc Vert Beach (France). CR Geosci 344:277-287

Bruneau N, Bonneton P, Pedreros R, Dumas F, Idier D (2007) A new morphodynamical modeling platform: application to characteristic sandy systems of the Aquitanian coast, France. J Coast Res 50:932-936

Butel R, Dupuis H, Bonneton P (2002) Spatial variability of wave conditions on the French Atlantic coast using insitu data. J Coast Res 36:96-108

- Calvete D, Dodd N, Falqués A, Van Leeuwen SM (2005) Morphological development of rip channel systems: normal and near normal wave incidence. J Geophys Res 110:C10006. doi:10.1029/2004JC002803

> Calvete D, Coco G, Falqués A, Dodd N (2007) (Un)predictability in rip channel systems. Geophys Res Lett 34: L05605. doi:10.1029/2006GL028162

Capo S, Bujan S, Parisot JP, Senechal N, Goriou T (2008) Evolution morphodynamique d'une plage du littoral Aquitain; la plage du Truc Vert en Gironde, France. Xèmes Journées Nationales Génie Côtier-Génie Civil (conference proceedings). SophiaAntipolis, 14-16 Oct 2008

> Cash DW, Clark WC, Alcock F, Dickson NM and others (2003) Knowledge systems for sustainable development. Proc Natl Acad Sci USA 100:8096-8091

Castelle B, Ruessink BG (2011) Modeling formation and subsequent nonlinear evolution of rip channels: timevarying versus time-invariant wave forcing. J Geophys Res 116:F04008. doi:10.1029/2011JF001997

> Castelle B, Bonneton P, Dupuis H, Sénéchal N (2007) Double bar beach dynamics on the high-energy meso-macrotidal French Aquitanian coast: a review. Mar Geol 245: 141-159

> Castelle B, Ruessink BG, Bonneton P, Marieu V, Bruneau N, Price TD (2010) Coupling mechanisms in double sandbar systems. 1. Patterns and physical explanation. Earth Surf Process Landf 35:476-486

> Certain R, Barusseau JP (2005) Conceptual modeling of sand bars morphodynamics for a microtidal beach (Sète, France). Bull Soc Geol Fr 176:343-354

Charles E, Idier D, Thiébot J, Le Cozannet G, Pedreros R, Ardhuin F, Planton S (2012a) Wave climate variability and trends in the Bay of Biscay from 1958 to 2001. J Clim 25:2020-2035

Charles E, Idier D, Delecluse P, Déqué M, Le Cozannet G (2012b) Climate change impact on waves in the Bay of Biscay, France. Ocean Dyn 62:831-848

> Chust G, Borja Á, Caballero A, Irigoien X and others (2011) Climate change impacts on coastal and pelagic environments in the southeastern Bay of Biscay. Clim Res 48: 307-332

Coelho C, Silva R, Veloso-Gomes F, Taveira-Pinto F (2006) A vulnerability analysis approach for the Portuguese west coast. In: Popov V, Brebbia CA (eds) Risk analysis V: simulation and hazard mitigation, Vol 91 - Transactions on ecology and the environment. Wessex Institute of Technology, Southampton
Cunderlink JM, Simonovic SP (2007) Inverse flood risk modelling under changing climatic conditions. Hydrol Processes 21:563-577

Dal Cin R, Simeoni U (1994) A model for determining the classification, vulnerability and risk in the southern coastal zone of the Marche (Italy). J Coast Res 10:18-29

> Deboudt P (2012) Testing integrated coastal management in France. Ocean Coast Manag 57:62-78

Eurosion (2004) Living with coastal erosion in Europe: sediment and space for sustainability. Directorate-General for Environment, European Commission, Brussels

Evans EP, Ashley R, Hall JW, Penning-Rowsell EC and others (2004a) Foresight future flooding, scientific summary, Vol 1 -Future risks and their drivers. Office of Science and Technology, London

Evans EP, Ashley R, Hall JW, Penning-Rowsell EC and others (2004b) Foresight future flooding, scientific summary, Vol 2-Managing future risks. Office of Science and Technology, London

Falqués A, Calvete D (2005) Large-scale dynamics of sandy coastlines: diffusivity and instability. J Geophys Res 110(C03007)

> Fattal P, Maanan M, Tillier I, Rollo N, Robin M, Ottier P (2010) Coastal vulnerability to oil spill pollution: the case of Noirmoutier island (France). J Coast Res 26:879-887

FLOODsite (2009) Integrated flood risk analysis and management methodologies (CD-Rom). FLOODsite Consortium, www.floodsite.net

García-Mora MR, Gallego-Fernández JB, Williams AT, García-Novo F (2001) A coastal dune vulnerability classification. A case study of the SW Iberian Peninsula. J Coast Res 17:802-811

> Garnier R, Calvete D, Falqués A, Dodd N (2008) Modelling the formation and the long-term behaviour of rip channel systems from the deformation of a longshore bar. J Geophys Res 113:C07053. doi:10.1029/2007JC004632

Gornitz, V (1990) Vulnerability of the East coast, USA to future sea level rise. J Coast Res, Spec Issue 9: 201-237

Gornitz, VM, Daniels RC, White TW, Birdwell KR (1994) The development of a coastal risk assessment database: vulnerability to sea-level rise in the US southeast. J Coast Res, Spec Issue 12: 327-338

- Grabemann I, Weisse R (2008) Climate change impact on extreme wave conditions in the North Sea: an ensemble study. Ocean Dyn 58:199-212

Gutiérrez BT, Plant NG, Thieler ER (2011) A Bayesian network to predict coastal vulnerability to sea level rise. J Geophys Res Earth Surface 116: F02009

Hall JW, Sayers PB, Walkden MJA, Panzeri I (2006) Impacts of climate change on coastal flood risk in England and Wales: 2030-2100. Philos T R Soc A364:1027-1049

- Hallegatte S, Przyluski V, Vogt-Schilb A (2011) Building world narratives for climate change impact, adaptation and vulnerability analyses. Nature Climate Change 1: 151-155

Hanson HH, Kraus NC (1989) GENESIS: generalized model for simulating shoreline change, Vol 1 - Reference manual and users guide. Technical Report CERC-89-19, US Army Engineer Waterways Experiment Station, Coastal Engineering Research Center, Vicksburg, MS

> Hanson S, Nicholls R, Ranger N, Hallegatte S, Corfee-Morlot J, Herweijer C, Chateau J (2011) A global ranking of port cities with high exposure to climate extremes. Clim Change 104:89-111

Hemer MA (2009) Identifying coasts susceptible to wave cli- 
mate change. J Coast Res SI56:228-232

Hervouet JM, Bates P (2000) The TELEMAC modelling system Special issue. Hydrol Proc 14 2207-2208

Howard T, Lowe J, Horsburgh K (2010) Interpreting century scale in southern North Sea storm surge climate derived from coupled model simulations. J Clim 23:6234-6247

Idier D, Boulahya F, Brivois O, Castelle B and others (2011a) Morphodynamic modeling: climate variability scenarios and sensitivity study. Application to the Truc Vert beach (France). Proc Coastal Sediments 2011, Miami, FL, May 2-6, 2011

Idier D, Falquès A, Garnier R, Ruessink G (2011b) Shoreline instability under low and shore-normal wave incidence. J Geophys Res Earth Surface 116:F04031

Idier D, Rohmer J, Bulteau T, Delvallée E (2012) An inverse methodology for coastal risk management. In: Klijn F, Schweckendiek T (eds) Comprehensive flood risk management. Taylor \& Francis Group, London

IPCC (2007a) Climate change 2007: the physical science basis. Summary for policymakers. Contribution of Working Group I to the Fourth Assessment Report of the Intergovernmental Panel on Climate Change. Cambridge University Press, Cambridge

IPCC (2007b) Climate change 2007: mitigation of climate change. Summary for policymakers. Contribution of WorkingGroup III to the Fourth Assessment Report of the Intergovernmental Panel on Climate Change. Cambridge University Press, Cambridge

Kabat P, Fresco LO, Stive MJF, Veerman CP and others (2009) Dutch coasts in transition. Nat Geosci 2:450-452

Komar PD (1998) Beach Processes and Sedimentation, 2nd edn. Prentice Hall, Englewood Cliffs, NJ

Larroudé P (2008) Methodology of seasonal morphological modeling for nourishment strategies on a Mediterranean beach. Mar Pollut Bull 57:47-52

Larson M, Capobianco M, Hanson H (2000) Relationship between beach profiles and waves at Duck, North Carolina, determined by canonical correlation analysis. Mar Geol 163:275-288

Le Cozannet G, Lecacheux S, Delvallée E, Desramaut N, Oliveros C, Pedreros R (2011) Teleconnection pattern influence on sea wave climate in the Bay of Biscay. J Clim 24:641-652

Le Cozannet G, Ait-Kaci A, Colas S, De Lacaze X and others (2013) Recent GIS-based national assessments of climate change consequences in France: methods, results, and lessons learnt. In: Conley DC, Masselink G, Russell PE, O'Hare TJ (eds) Proc 12th Int Coastal Symp (Plymouth, England). J Coast Res Spec Issue 65, http://ics2013.org/ papers/Paper3649_rev.pdf

Lima ML (1998) Os factores sociais na percepção do risco. Psicologia 12:11-28

> Lozano I, Devoy RJN, May W, Andersen U (2004) Storminess and vulnerability along the Atlantic coastlines of Europe: analysis of storm records and of a greenhouse gases induced climate scenario. Mar Geol 210:205-225

- Marcos M, Tsimplis MN (2008) Comparison of results of AOGCMs in the Mediterranean Sea during the 21st century. J Geophys Res 113:C12028. doi:10.1029/2008 JC004820

Marcos M, Chust G, Jordà G, Caballero A (2012) Effect of sea level extremes on the western Basque coast during the 21st century. Clim Res 51:237-248

Martínez ML, Gallego-Fernández JB, García-Franco JG, Moctezuma C, Jiménez CD (2006) Assessment of coastal dune vulnerability to natural and anthropogenic disturbances along the Gulf of Mexico. Environ Conserv 33: 109-117

Maspataud A, Ruz MH, Héquette A (2009) Spatial variability in post-storm beach recovery along a macrotidal barred beach, southern North Sea. J Coast Res Spec Issue 56: 88-92

McInnes RG, Jakeways J, Fairbank H (2006) Responseresponding to the risks from climate change. Final report of the European Commission LIFE project. Isle of Wight Centre for the Coastal Environment, Ventnor

MEDDE (2011) National plan - Climate chance adaptation (http://www.developpement-durable.gouv.fr/IMG/pdf/ ONERC_PNACC_Eng_part_1.pdf)

> Meyssignac B, Cazenave A (2012a) Sea level: a review of present-day and recent-past changes and variability. J Geodyn 58:96-109

Michel D, Howa HL (1994) Morphological evolution of a littoral sandy bank, modelisation of its dynamics. II. Vol. 12. Annals Geophysicae, European Geophysical Union, Grenoble

> Nicholls RJ (2011) Planning for the impacts of sea level rise. Oceanography 24(2):144-157

Nicholls RJ, Wong PP, Burkett VR, Codignotto JO and others (2007) Coastal systems and low-lying areas. In: Parry ML, Canziani OF, Palutikof JP, van der Linden PJ, Hanson CE (eds) Climate Change 2007: impacts, adaptation and vulnerability. Contribution of Working Group II to the Fourth Assessment Report of the Intergovernmental Panel on Climate Change. Cambridge University Press, Cambridge, p 315-356

OECD (Organisation for Economic Co-operation and Development) (2008) Handbook on constructing composite indicators: methodology and user guide. www.oecd.org/ std/clits/42495745.pdf

Parisot JP, Capo S, Rihouey D, Howa H, Desmazes F, Fauque L (2010) Analyse de l'évolution morphodynamique de la plage du Truc Vert (Gironde) sur une période décennale. XIème Journées Nationales Génie Côtier-Génie Civil (conference proceedings). Sables d'Olonne, 22-24 Jun 2010

Pickands J (1975) Statistical inference using extreme order statistics. Ann Stat 3:119-131

Poumadère $\mathrm{M}$, Bohn Bertoldo $\mathrm{R}$, Balouin $\mathrm{Y}$, Idier $\mathrm{D}$ and others (2010) Gouvernance des risques climatiques et vulnérabilité du littoral: méthodologie du scénario, de l'atelier de parties prenantes et des représentations sociales. In: BRGM (ed) Recueil des actes du colloque des 'Journées impact du changements climatique sur les risques côtiers' (workshop proceedings). 45060 Orléans, France, 15-16 Nov 2010, p 125-128. www.brgm.fr/ content/journees-impacts-changement-climatique-surrisques-cotiers

Ranasinghe R, McLoughlin R, Short A, Symonds G (2004) The Southern Oscillation Index, wave climate, and beach rotation. Mar Geol 204:273-287

> Roelvink D, Reniers A, van Dongeren A, van Thiel de Vries J, McCall R, Lescinski J (2009) Modelling storm impacts on beaches, dunes and barrier islands. Coast Eng 56: 1133-1152

> Rohmer J, Idier D (2012) A meta-modelling strategy to identify the critical offshore conditions for coastal flooding. Nat Hazards Earth Syst Sci 12:2943-2955

> Rozynski G (2010) Long-term evolution of Baltic Sea wave climate near a coastal segment in Poland; its drivers and impacts. Ocean Eng 37:186-199 
Ruz MH, Héquette A, Maspataud A (2009) Identifying forcing conditions responsible for foredune erosion in the northern coast of France. J Coast Res Spec Issue 56: 356-360

Sallenger AH Jr (2000) Storm impact scale for barrier islands. J Coast Res 16:890-895

Sénéchal N, Gouriou T, Castelle B, Parisot JP, Capo S, Bujan S, Howa H (2009) Morphodynamic response of a mesoto macro-tidal intermediate beach based on a long term data set. Geomorphology 107:263-274

Sénéchal N, Abadie S, Gallagher E, MacMahan JHM and others (2011) The ECORS-Truc Vert'08 nearshore field experiment: presentation of a three-dimensional morphologic system in a macro-tidal environment during consecutive extreme storm conditions. Ocean Dyn 61 Suppl 1: 2073-2098

Slangen ABA, Katsman CA, van de Wal RSW, Vermeersen LLA, Riva REM (2012) Towards regional projections of twenty-first century sea-level change based on IPCC SRES scenarios. Clim Dyn 38:1191-1209

Tastet JP, Nigel IP (1998) Morpho-chronology of coastal dunes in Médoc. A new interpretation of Holocène dunes in southwestern France. Geomorphology 25:93-109

Thiébot J, Idier D, Garnier R, Falqués A, Ruessink G (2012) The influence of wave direction on the morphological response of a double sandbar system. Cont Shelf Res 32: 71-85

Thomas T, Phillips MR, Williams AT (2010) Mesoscale evolution of a headland bay: beach rotation processes. Geomorphology 123:129-141

Thomas T, Phillips MR, Williams AT, Jenkins RE (2012) Medium time-scale behaviour of adjacent embayed beaches: influence of low energy external forcing. Appl Geogr 32:265-280

Thornton EB, MacMahan J, Sallenger AH Jr (2007) Rip currents, mega-cusps, and eroding dunes. Mar Geol 240: 151-167

Tolman HL (1991) A third-generation model for wind waves on slowly varying, unsteady and inhomogeneous depths and currents. J Phys Oceanogr 21:782-797

Trope Y, Liberman N (2003) Temporal construal. Psychol Rev 110:403-421

Tsimplis MN, Woolf DK, Osborn TJ, Wakelin S and others (2005) Towards a vulnerability assessment of the UK and

Editorial responsibility: Nils Chr. Stenseth, Oslo, Norway northern European coasts: the role of regional climate variability. Phil Trans R Soc A 363:1329-1358

UNEP/GRID-Arendal (2007) Coastal population and altered land cover in coastal zones (100 km of coastline). UNEP/ GRID-Arendal Maps and Graphics Library. http://maps. grida.no/go/graphic/coastal-population-and-alteredland-cover-in-coastal-zones-100-km-of-coastline

van Enckevort IMJ, Ruessink BG, Coco G, Suzuki K, Turner IL, Plant NG, Holman RA (2004) Observations of nearshore crescentic sandbars. J Geophys Res 109(C06028). doi:10.1029/2003JC002214

Vinchon C, Aubié S, Balouin Y, Closset L, Garcin M, Idier D, Mallet C (2009) Anticipate response of climate change on coastal risks at regional scale in Aquitaine and Languedoc-Roussillon (France). Ocean Coast Manag 52:47-56

Wang S, McGrath R, Hanafin J, Lynch P, Semmler T, Nolan $P$ (2008) The impact of climate change on storm surges over Irish waters. Ocean Model 25:83-94

Woolf DK, Challenor PG, Cotton PD (2002) Variability and predictability of the North Atlantic wave climate. J Geophys Res C 107:3145-3159

- Woolf DK, Shaw AGP, Tsimplis MN (2003) The influence of the North Atlantic Oscillation on sea-level variability in the North Atlantic region. J Atmos Ocean Sci 9:145-167

Wöppelmann G, Marcos M (2012) Coastal sea level rise in southern Europe and the nonclimate contribution of vertical land motion. J Geophys Res C 117: C01007

> Woth K, Weisse R, von Storch H (2006) Climate change and North Sea storm surge extremes: an ensemble study of storm surge extremes expected in a changed climate projected by four different regional climate models. Ocean Dyn 56:3-15

> Wright LD, Short AD (1984) Morphodynamic variability of beaches and surf zones: a synthesis. Mar Geol 56:93-118

> Yates ML, Le Cozannet G (2012) Brief communication 'evaluating European coastal evolution using Bayesian networks'. Nat Hazards Earth Syst Sci 12:1173-1177

Zanuttigh B (2011) Coastal flood protection: what perspective in a changing climate? The THESEUS approach. Environ Sci Policy 14:845-863

Zhang K, Douglas BC, Leatherman SP (2001) Beach erosion potential for severe nor'easters. J Coast Res 17:309-321

Zhang KQ, Douglas BC, Leatherman SP (2004) Global warming and coastal erosion. Clim Change 64:41-58

Submitted: June 9, 2011; Accepted: January 27, 2013

Proofs received from author(s): June 4, 2013 